\title{
Article \\ Assessment of Heavy Metals in Agricultural Soils and Plant (Vernonia amygdalina Delile) in Port Harcourt Metropolis, Nigeria
}

\author{
William Azuka Iyama ${ }^{1,2}$, Kingsley Okpara ${ }^{1}$ and Kuaanan Techato ${ }^{1, *(D)}$ \\ 1 Faculty of Environmental Management, Prince of Songkla University, Hat Yai, Songkhla 90110, Thailand; \\ williamiyama@rschst.edu.ng (W.A.I.); okparakingsley777@gmail.com (K.O.) \\ 2 Jaros Inspection Services Ltd. Laboratory, Rivers State University, Port Harcourt 5080, Nigeria \\ * Correspondence: kuaanan.t@psu.ac.th
}

Citation: Iyama, W.A.; Okpara, K.; Techato, K. Assessment of Heavy Metals in Agricultural Soils and Plant (Vernonia amygdalina Delile) in Port Harcourt Metropolis, Nigeria. Agriculture 2022, 12, 27. https:// doi.org/10.3390/agriculture 12010027

Academic Editor: Nguyen V. Hue

Received: 31 October 2021

Accepted: 18 December 2021

Published: 27 December 2021

Publisher's Note: MDPI stays neutral with regard to jurisdictional claims in published maps and institutional affiliations.

Copyright: (c) 2021 by the authors. Licensee MDPI, Basel, Switzerland. This article is an open access article distributed under the terms and conditions of the Creative Commons Attribution (CC BY) license (https:// creativecommons.org/licenses/by/ $4.0 /)$.

\begin{abstract}
This study assessed the concentration of heavy metal, such as lead (Pb), cadmium (Cd), Chromium (Cr), iron (Fe), Nickel (Ni), and Silver (Ag), in Vernonia amygdalina Delile and agricultural soils of three university farms located in Port Harcourt, Nigeria. The soils and plants were taken randomly to form composite samples and analyzed for heavy metals by the use of atomic absorption spectroscopy (AAS) and X-ray fluorescence (XRF). The study stations were agricultural soils and Vernonia amygdalina Delile from the Ignatius Ajuru University of Education (I), River State University (R) and University of Port Harcourt (U). The soil samples recorded mean concentration ranges for Fe as $19.71 \pm 1.77(\mathrm{I})-27.24 \pm 3.56 \mathrm{mg} / \mathrm{kg}(\mathrm{R})$ in soils and $12.95 \pm 1.68(\mathrm{R})-18.18 \pm 2.02 \mathrm{mg} / \mathrm{kg}(\mathrm{U})$ for the bitter leaf samples. The mean range for $\mathrm{Pb}$ concentration in the soil and bitter leaf were $4.35 \pm 0.87-6.80 \pm 0.86 \mathrm{mg} / \mathrm{kg}$ and $0.24 \pm 0.64-2.19 \pm 0.74 \mathrm{mg} / \mathrm{kg}$, while Cd concentration in the soil and bitter leaf were $0.46 \pm 0.28-1.42 \pm 0.40 \mathrm{mg} / \mathrm{kg}$ and $0.17 \pm 0.22-0.42 \pm 0.08 \mathrm{mg} / \mathrm{kg}$, respectively. The respective mean ranges for $\mathrm{Cr}$ concentration in the soil and bitter leaf were $5.91 \pm 1.14-8.77 \pm$ $0.88 \mathrm{mg} / \mathrm{kg}$ and $4.04 \pm 0.64-5.92 \pm 0.69 \mathrm{mg} / \mathrm{kg}$, while $\mathrm{Ni}$ in soil and bitter leaf were $0.54 \pm 3.38-10.26$ $\pm 3.50 \mathrm{mg} / \mathrm{kg}$ and $0.042 \pm 1.42-3.30 \pm 0.88 \mathrm{mg} / \mathrm{kg}$, while Ag was negligible. Heavy metal levels in soils and Vernonia amygdalina followed the order $\mathrm{Fe}>\mathrm{Cr}>\mathrm{Pb}>\mathrm{Ni}>\mathrm{Cd}$ and $\mathrm{Fe}>\mathrm{Cr}>\mathrm{Ni}>$ $\mathrm{Pb}>\mathrm{Cd}$, respectively, and were lower than WHO/FAO and EPA, except $\mathrm{Cd}$, which was higher in soil and in Vernonia amygdalina. The ecological risk factor $(E r F)$ was comparatively lower in soils than in the plant, while pollution load index (PLI) showed high heavy metal retention capacities in Vernonia amygdalina due to more anthropogenic influences. The metal transfer factor (TF) was highest in $\mathrm{Fe}$, followed by $\mathrm{Cr}>\mathrm{Cd}>\mathrm{Ni}>\mathrm{Pb}$, while $\mathrm{Pb}$ had the highest chances of cancer risks from the incremental lifetime cancer risk (ILCR), especially in both soil and plant (mean ILCR, $2.07 \times 10^{-2}$ and $2.45 \times 10^{-3}$ ), while $C d$ had the least (mean $I L C R, 9.64 \times 10^{-5}$ and $3.36 \times 10^{-5}$ ). Anthropogenic activities must be regulated and monitored by government relevant agencies to reduce heavy metal inputs into soils and avoid excessive accruals in food chain.
\end{abstract}

Keywords: agricultural soil; Vernonia amygdalina Delile; heavy metal; pollution load index; cancer risk; transfer factor

\section{Introduction}

Several research studies have shown that heavy metal contamination and pollution emanate principally from natural and anthropogenic activities [1,2]. Any metal considered toxic or hazardous may be called heavy metal; toxic heavy metals (THM), such as lead $(\mathrm{Pb})$, cadmium $(\mathrm{Cd})$, chromium $(\mathrm{Cr})$, nickel $(\mathrm{Ni})$, and iron $(\mathrm{Fe})$, contaminate agricultural soils and crops, such as garden vegetables, grains, and fruits, due to their concomitant and detrimental complications from their persistence and non-biodegradability [3,4]. By definition, heavy metals (HM) are metals of specific high densities greater than $5 \mathrm{~g} / \mathrm{cm}^{3}$ and of high molecular mass, transition metal, and of negative effects on the living things 
and the ecosystem [5]. According to Singh [6], it is irrespective of the weight, atomic mass, or density. Contamination of soils may emanate from heavy metal and metalloids accumulation through many anthropogenic activities, ranging from heavy metal disposal to deposition in the air [7]. Heavy metals are causes of environmental pollution from different from dictionary of Chemistry. The main sources of toxic metals are anthropogenic inputs and industrial wastes [8]. Currently, pollution has increased due to increasing anthropogenic inputs ranging from burning of fossil fuels to exhaust emissions, which were noted as major sources of metallic burden in the atmospheric [7,9]. Research showed that different automobiles released various kinds of hazardous metals into the ecosystem [10].

According to Khan et al. [3], soil can act as either a sink or source. There are myriads of pollution, such as soil pollution, affecting living organisms, which include the crops. Chemical features of soils are dependent on the kind of weathered rocks (e.g., the mafic and ultramafic classes) in study areas leading to contamination of both soil and crops $[1,11,12]$. Vernonia amygdalina Delile being a staple diet can act as buffer during digestion processes and may contain both essential and non- essential metals [12-14]. Metals, such as Cd, $\mathrm{Cr}, \mathrm{Pb}, \mathrm{Ni}$, and $\mathrm{Fe}$, can be toxic and, when accumulated over time, can be detrimental to human health $[3,15]$. Food contaminated by $\mathrm{Cd}$ can result in acute and chronic health challenges, such as artery problems and others $[12,16,17]$. Ingestion of $\mathrm{Ni}$ can cause cardiac arrest, fatigue, heart issues, and respiratory diseases [4]. Exposure to $\mathrm{Pb}$ and $\mathrm{Cd}$ (most abundant HMs in vegetables) can pose various health challenges, such as heart, kidney, and bone diseases. Therefore, obtaining the levels of these HMs in the soil and plant (Vernonia amygdalina) can help in estimating their concentration in the edible leaf part [18].

Study revealed that Vernonia amygdalina leaf has high mineral content and is used as a vegetable [19]. Bitter leaf is of either grey or brown colored bark, a rough texture, and is flaked [20]. Vernonia amygdalina is medicinal and contains both essential and toxic metals over a wide range of concentrations [21,22].

Studies on Vernonia amygdalina to determine concentrations of $\mathrm{Cd}, \mathrm{Pb}, \mathrm{Cr}, \mathrm{Ni}$, and $\mathrm{Ag}$ on garden soils from these tertiary institutions have not been done especially looking at the health risks using transfer factor $(T F)$, contamination factor $(C F)$, pollution load indices $(P L I)$, enrichment factor $(E F)$, ecological risk factor, chronic daily intake ingestion, hazard index (HI), and carcinogenic analysis [12,23-25]. Hence, this study will evaluate the level of heavy metals of interest from the locations $(\mathrm{Fe}, \mathrm{Pb}, \mathrm{Cr}, \mathrm{Cd}, \mathrm{Ni}$, and $\mathrm{Ag}$ ) and determine the levels of ecological and health risks impacts. The government pressure and focus on farming by the citizens increases the need to grow this plant even at subsistence level; hence, the adjacent soil content must be known to in monitoring, prevention, and control of contamination and subsequent pollution.

\section{Materials and Methods}

\subsection{Study Stations}

The research study was done on three campuses: Uniport (U), Rivers State University (RSU, R), and the Ignatius Ajuru University of Education (IAUE, I). The map of the sampling locations appears in Figure 1 whose locations were determined using geographic positioning system (GPS). The control stations have the following coordinates: I $\left(4^{\circ} 48^{\prime} 42^{\prime \prime} \mathrm{N}\right.$, $\left.6^{\circ} 56^{\prime} 40^{\prime \prime} \mathrm{E}\right), \mathrm{R}\left(4^{\circ} 48^{\prime} 20^{\prime \prime} \mathrm{N}, 6^{\circ} 59^{\prime} 16^{\prime \prime} \mathrm{E}\right.$, and $\mathrm{U}\left(4^{\circ} 53^{\prime} 56^{\prime \prime} \mathrm{N}, 6^{\circ} 54^{\prime} 15^{\prime \prime} \mathrm{E}\right)$, as shown in the figure below. 


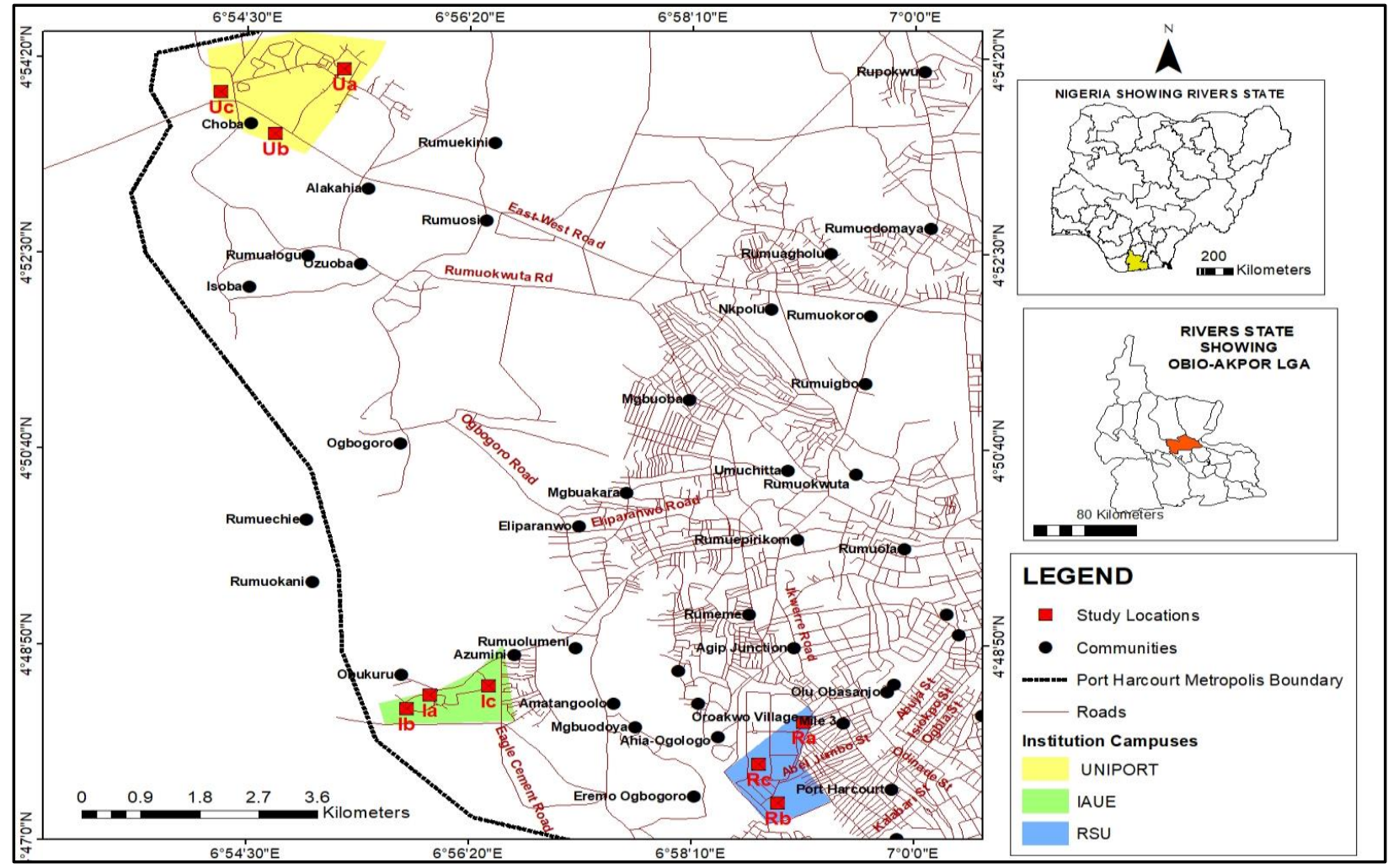

Figure 1. Map of the study locations, I, R, and U (source: Digitized from Ministry of Lands/Survey, Port Harcourt).

\subsection{Sampling and Pre-Treatment Procedures}

\subsubsection{Soil Sampling}

Samples of soils were taken randomly from a depth of $0-15 \mathrm{~cm}$ using the stainless steel auger from three locations. Each soil sample was prepared by firstly collecting many sub-soil samples around each sampling site, followed by thorough mixing of the samples to form the composite sample $(1 \mathrm{~kg})$ using the quartile technique. The sample was then sealed in a clean polyethylene bag and transported to the Jaros Inspection Services Ltd., Laboratory, KM 2 Iwofe Road, Rumueprikom, P.M.B.6150, Port Harcourt, Rivers State, (+234-33486693) Nigeria. After oven-drying (at $105^{\circ} \mathrm{C}$ ) for six hours, the soil samples were grounded mechanically and passed through a $1.18-\mathrm{mm}$ sieve and stored for further analysis.

\subsubsection{Vernonia Amygdalina Delile Sampling}

The samples from bitter leaf were taken from the three study sites of $I, R$, and $U$ ( $n=36$ samples from 4 study stations) at the same points where the soil samples were collected. The bitter leaf was taken from the three sampling spots, while the controls were outside the campuses. These were then put into separate polythene bags and labeled accordingly. They were then taken immediately to the laboratory for further handling and analysis. The samples of the vegetable were thoroughly washed with both tap water and de-ionized water to remove air pollutants. Finally, the samples were oven-dried at $105^{\circ} \mathrm{C}$ for $48 \mathrm{~h}$ to remove moisture and pulverized. This was achieved by the use of agate pestle and mortar. Similarly, sieving was done using a $0.5 \mathrm{~mm}$ mesh size sieve to obtain a uniform particle size. Each sample was labeled and stored in a dry plastic container that had been pre-cleaned with concentrated nitric acid $\left(\mathrm{HNO}_{3}\right)$ to prevent contamination prior to analysis (X-ray fluorescence spectrometer). The determination of heavy metal was done in accordance with standard procedures. 


\subsection{Extraction Procedures}

\subsubsection{Agricultural Soil Extraction}

The collected soil samples were extracted using the wet digestion method (WDM). Afterwards, thorough digestion of the representative soil samples was done. One gram ( $1 \mathrm{~g})$ dried powdered soil was put into a $50 \mathrm{~mL}$ conical flask, and, later, a $15 \mathrm{~mL}$ sample digested in $10 \mathrm{~mL}$ of $1: 1 \mathrm{HNO}_{3}: \mathrm{H}_{2} \mathrm{SO}_{4}$ mixture, heated to $95{ }^{\circ} \mathrm{C}$ to dry, and thereafter refluxed for $10 \mathrm{~min}$ without boiling. After cooling, $5 \mathrm{~mL}$ of concentrated $\mathrm{HNO}_{3}$ was once again added and refluxed for $30 \mathrm{~min}$ till brown fumes were produced. The solution was vaporized to about $5 \mathrm{~mL}$ on mantle set at $95{ }^{\circ} \mathrm{C}$ with a watch glass over it. After cooling the resulting sample, $2 \mathrm{~mL}$ of $\mathrm{H}_{2} \mathrm{O}$ and $3 \mathrm{~mL}$ of $30 \% \mathrm{H}_{2} \mathrm{O}_{2}$ were added, and the solution was placed on the heating mantle to start the oxidation of peroxide until effervescence subsided. The vessel was cooled and the acid-peroxide digestate heated to about $5 \mathrm{~mL}$ at $95{ }^{\circ} \mathrm{C}$. Later, $10 \mathrm{~mL}$ of concentrated hydrochloric acid $(\mathrm{HCl})$ was added to the sample digest, and the solution was placed on the heating source and refluxed for $15 \mathrm{~min}$ at $95^{\circ} \mathrm{C}$. The Whatman No. 42 filter paper was used to filter the obtained digestate, put into a $100 \mathrm{~mL}$ volumetric flask, and then made up to the mark with distilled water. Finally, the filtrate was taken for analysis. Heavy metal analysis was done using the Atomic Absorption Spectrophotometer (ASTMD 1971/4691) (SAI Global Standards, Chicago, IL, USA), solar thermos elemental flame atomic absorption spectrometer, model SE-71096 made in Germany with detection limit of $0.001 \mathrm{mg} \cdot \mathrm{kg}^{-1}$ at Jaros Inspection Services Ltd., Iwofe Road, Port Harcourt, Nigeria. The AAS was fitted with specific lamp of a particular heavy metal, while the other conditions were the same [26].

\subsubsection{Vernonia Amygdalina Delile Extraction}

Then, $2.0 \mathrm{~g}$ of Vernonia amygdalina Delile, $15 \mathrm{mls}$ of perchloric $\left(\mathrm{HClO}_{4}\right)$, and trioxonitrate $\mathrm{V}$ acid solution were mixed in the ratio of 1:4. After been left overnight, cold digestion was done and heated on hot plate until a transparent solution was observed, but at different temperatures. After cooling, the digested samples were filtered using the What man filter paper No. 42, then diluted up to $100 \mathrm{~mL}$ by volume using highly purified deionized water, and stored at room temperature for further analytical procedures.

\subsection{Analytical Procedures}

Sample preparations and analysis utilized high grade chemicals of high spectroscopic purity of $99.9 \%$ (Merck Darmstadt, Darmstadt, Germany). To obtain high standards, solutions of $\mathrm{Fe}, \mathrm{Pb}, \mathrm{Cd}, \mathrm{Cr}, \mathrm{Ag}$, and $\mathrm{Ni}$ were prepared diluting their respective $1000 \mathrm{mg} / \mathrm{L}$ standard solutions (Fluka Kamica, Busch, Switzerland). The final analysis for both soils and Vernonia amygdalina extracts were done using atomic absorption spectrophotometer AAS (Perkin Elmer AAS-700, Darmstadt, Germany). To determine accuracy and precision, blank reagents and standard reference materials (SRMs) of the studied heavy metals were used for digestion. To ascertain quality assurance, each sample batch was analyzed in triplicate under standard conditions at $95 \%$ confidence level. The instrumental conditions and detection limits for selected HMs are based on standard conditions. Appropriate quality assurance procedures and precautions were taken to ensure the reliability of the results. Samples were carefully handled to avoid cross-contamination. Deionized water was used throughout the study. Reagent blank determinations were used to apply corrections to the instrument readings. For validation of the analytical procedure, repeated analyses of the samples against internationally certified plant standard reference material (SRM) of the National Institute of Standard and Technology were used, and the results were found to lie within $\pm 1 \%$ of the certified values. Measurements were made using standard hollow cathode lamps for $\mathrm{Pb}, \mathrm{Cd}, \mathrm{Cr}$, and $\mathrm{Ni}$. The limit of detection (LOD) of the analytical method for each metal was calculated as being triple the standard deviation of a series of measurements for each solution. The concentration of which is distinctly detectable above the background level. These values were $0.001,0.001,0.001$, and $0.002 \mathrm{mg} / \mathrm{kg}$ for $\mathrm{Pb}, \mathrm{Cd}$, $\mathrm{Cr}$, and $\mathrm{Ni}$, respectively. In addition, the limit of quantification (LOQ) of the element was 
determined; these were calculated as $0.003,0.003,0.003$, and $0.007 \mathrm{mg} / \mathrm{kg}$ for $\mathrm{Pb}, \mathrm{Cd}, \mathrm{Cr}$, and $\mathrm{Ni}$, respectively.

\subsection{Research and Sampling Designs}

The pure experimental (experimental with control) and cross-sectional survey designs (samples were taken at different points in time) were adopted for the study.

\subsection{Statistical Analysis}

The mean, standard deviation, analysis of variance (one-way ANOVA), $t$-test, and Pearson's product moment correlation coefficient were used to determine the spatial relationships in the study stations and concentrations, as well as also for that between two different stations, respectively, at $95 \%$ confidence level $(p \leq 0.05)$. Similarly, different health risk assessment models and graphs were used to illustrate existing trends around the three campuses to ascertain the health implications.

\subsection{Risk Assessment Models}

1. Transfer Factor (TF)

The results for soil and the bitter leaf were employed to determine the transfer factor (TF) as given in the following equation [27].

$$
T F=\frac{[\text { Heavy metals }] \text { bitter leaf } \mathrm{mg} \cdot \mathrm{kg}^{-1}}{[\text { Heavy metal }] \times \text { soil } \mathrm{mg} \cdot \mathrm{kg}^{-1}}
$$

where [Heavy metals]bitterleaf $\mathrm{mg} \cdot \mathrm{kg}^{-1}=$ Concentration of heavy metal in bitter leaf $\left(\mathrm{mg} \cdot \mathrm{kg}^{-1}\right) ;[$ Heavy metal $] \times$ soil $\mathrm{mg} \cdot \mathrm{kg}^{-1}=$ Concentration of heavy metal in the soil $\left(\mathrm{mg} \cdot \mathrm{kg}^{-1}\right)$.

2. Contamination Factor $(C F)$ :

The Contamination Factor $(C F)$ is calculated using Equation (2) and shows site specific contamination of toxic substances [28].

$$
C F=\frac{C_{m}(\text { sample })}{C_{m}(\text { background })}
$$

where $C_{m}($ sample $)=$ metal concentration at a contaminated site; $C_{m}($ background $)=$ concentration of a given element in background sample. The $C F$ is based on 4 categories of contamination: Low $(C F<1)$, moderate $(1<C F<3)$, considerable $(3>C F<6)$, and very high $(C F>6)$ [29].

3. Pollution Load Index (PLI):

This can be determined using Equation (3) [30].

$$
P L I=\left(C F 1 \times C F 2 \times C F 3 \ldots C F_{n}\right)^{1 / n}
$$

where $C F=$ contamination factor, $n=$ number of study metals, $C_{\text {metal }}=$ metal pollutant concentration in soil; $C_{\text {background }}=$ metal background value.

\section{Enrichment Factor $(E F)$ :}

This can be evaluated using Equation (4).

$$
E F=\left(\frac{C_{\text {metal }}}{C_{\text {normalizer }}}\right) /\left(C_{\text {metal }} / C_{\text {normalizer }}\right) \text { control }
$$

where $C_{\text {metal }}$ and $C_{\text {normalizer }}$ are concentrations of heavy metal and normalizer in soil and control, respectively. $E F$ value is used to differentiate magnitude of contamination resulting from either the natural or human influence [31]. 
5. Ecological Risk Factor $\left(E_{r} F\right)$ and Potential Ecological Risk Factor $(R I)$ :

The $E_{r} F$ and $R I$ can be calculated using Equations (5) and (6), respectively [32].

$$
E r F=T R \times C F
$$

where $T R=$ toxic response factor, and $C F=$ contamination factor.

$$
R I=\sum E r F
$$

Interpretations of $E r F$ and $R I$ are as follows; $E r F<40$ and $R I<150$ is low risk; $40 \leq E r F$ $<160$ and $150 \leq R I<300$ is moderate risk; $80 \leq E r F<160,300 \leq R I<600$ is considerable risk; $160 \leq E r F<320$ is high; $E r F \geq 320$ and $R I \geq 600$.

6. Chronic Daily Intake $\left(C D I_{\text {ing }}\right)$ via ingestion:

The result could be obtained using Equation (7) below.

$$
C D \text { Iing }=C_{\text {soil }} \times \operatorname{Ring} \times E F \times \frac{E D}{B W} \times A T \times 10^{-6} .
$$

$R=$ Rate of ingestion (100 mg/day in adult and $200 \mathrm{mg} /$ day in children), $E F=$ exposure frequency, $E D=$ exposure duration ( 24 years in adults and 6 years in children), $B W=$ body weight of the individual exposed (70 kg in adults, $15 \mathrm{~kg}$ in children), $A T=$ averaging time in days (365 $\times E D$ adult/children) (Reference dose $\left(R_{f} D\right)$ for metals are: $\mathrm{Fe}=0.7, \mathrm{~Pb}=0.0035$, $\mathrm{Cd}=0.001, \mathrm{Cr}=0.003$, and $\mathrm{Ni}=0.0008)$ [33].

\section{Hazard Quotient $(H Q)$ :}

$H Q$ is determined using Equation (8). If the $H Q<1$, no obvious risk, but, if $H Q>1$, then, risk is obvious.

$$
H Q=\frac{C D I}{R f D}
$$

$C D I=$ chronic daily intake, and $R f D$ is the oral reference dose for the metal $\left(\mathrm{mg} \mathrm{kg}^{-1}\right.$ of body weight per day); $R f D=$ estimate of a daily oral exposure for the human population which does not cause deleterious effects during a lifetime, generally used in EPA's non-cancer health assessments, and values of $R f D$ for $\mathrm{Cd}\left(0.001 \mathrm{mg} \mathrm{kg}^{-1}\right.$ per day), Ni (0.02 $\mathrm{mg} \mathrm{kg}^{-1}$ per day), and $\mathrm{Cr}\left(1.5 \mathrm{mg} \mathrm{kg}^{-1}\right.$ per day) were taken from Integrated Risk Information System [34]. The value of $R f D$ for $\mathrm{Pb}\left(0.0035 \mathrm{mg} \mathrm{kg}^{-1}\right.$ per day) was taken from known WHO [34] standards. The average Bo was taken as $70 \mathrm{~kg}$ for adults [34], and $19.25 \mathrm{~kg}$ for children 0-6 years old [35].

\section{Hazard Index $(H I)$ :}

The hazard index can be calculated using Equation (9). $H I<1$ means no risk from non-carcinogenic effects; $H I>1$ means adverse health effects possible and has probability of effects increasing with the increases in the $H I$ value.

$$
H I=\sum H Q=H Q F e+H Q C d+H Q C r+H Q N i
$$

\section{Carcinogenic Analysis (ILCR)}

The ILCR is calculated using Equation (10), and it is defined as the incremental probability of a person developing any type of cancer over a lifetime as a result of twenty-four hours per day exposure to a given daily amount of a carcinogenic element for seventy years [36]. Equation (10) is commonly used for the calculation of the lifetime cancer risk.

$$
I L C R=C D I C S F
$$


where CSF is the cancer slope factor, and CSF for the metals is $\mathrm{Cd}-0.38, \mathrm{Cr}-0.5, \mathrm{~Pb}-0.0085$, and $\mathrm{Fe}-0$ [34], and $\mathrm{CDI}$ is the chronic daily intake. The permissible limits are considered to be $10^{-6}$ and $<10^{-4}$ for a single carcinogenic element and multi-element carcinogens [37].

\section{Results and Discussions}

The summary of results is shown in Table 1; Table 2 shows that for both soils and the Vernonia amygdalina leaf (bitter leaf). The soil samples recorded mean concentration ranges for Fe as $19.71 \pm 1.77(\mathrm{I})-27.24 \pm 3.56(\mathrm{R})$ in soils across the stations and $12.95 \pm 1.68(\mathrm{R})-18.18 \pm 2.02(\mathrm{U})$ for the bitter leaf samples. The mean ranges for $\mathrm{Pb}$ concentration in the soil and bitter leaf were $4.35 \pm 0.87$ (R)-6.80 \pm 0.86 (I) and $0.24 \pm$ $0.64-2.19 \pm 0.74$, respectively. The mean ranges for $\mathrm{Cd}$ concentration in the soil and bitter leaf were $0.46 \pm 0.28(\mathrm{I})-1.42 \pm 0.40(\mathrm{U})$ and $0.17 \pm 0.22(\mathrm{U})-0.42 \pm 0.08(\mathrm{U})$, respectively. The mean ranges for $\mathrm{Cr}$ concentration in the soil and bitter leaf were $5.91 \pm 1.14(\mathrm{R})-8.77 \pm$ $0.88(\mathrm{U})$ and $4.04 \pm 0.64(\mathrm{U})-5.92 \pm 0.69(\mathrm{I})$, respectively. These stations recorded respective concentration ranges of $\mathrm{Ni}$ for the soil and bitter leaf as $0.54 \pm 3.38$ (I)-10.26 \pm 3.50 (R) and $0.04 \pm 1.42-3.30 \pm 0.88(\mathrm{R})$. The mean ranges of concentration for Ag were $0.001 \pm$ 0.00 (I) $-0.00 \pm 0.00$ ( $R$, soil) and $0.00 \pm 0.00$ (I)-0.00 \pm 0.00 (I, bitter leaf).

Table 1. Mean concentration of heavy metals in soils of campuses (I, R, U).

\begin{tabular}{cccccccc}
\hline & \multicolumn{7}{c}{ Sample Stations } \\
\hline $\begin{array}{c}\text { Heavy } \\
\text { Metals(mg/kg) }\end{array}$ & $\mathbf{I}$ & Control (Ic) & $\mathbf{R}$ & Control (Rc) & U & Control & Mean (I, R, U) \\
\hline $\mathrm{Fe}$ & $19.71 \pm 1.77$ & $22.51 \pm 2.25$ & $27.24 \pm 3.56$ & $27.57 \pm 2.37$ & $19.69 \pm 1.78$ & $20.55 \pm 2.50$ & 22.21 \\
$\mathrm{~Pb}$ & $6.80 \pm 0.86$ & $7.36 \pm 1.20$ & $4.35 \pm 0.87$ & $5.35 \pm 0.46$ & $5.60 \pm 0.01$ & $6.40 \pm 1.40$ & 2.98 \\
$\mathrm{Cd}$ & $0.46 \pm 0.28$ & $0.50 \pm 0.24$ & $0.71 \pm 0.11$ & $0.75 \pm 0.21$ & $1.42 \pm 0.40$ & $2.40 \pm 0.50$ & 0.87 \\
$\mathrm{Cr}$ & $8.77 \pm 0.88$ & $8.78 \pm 0.56$ & $5.91 \pm 1.14$ & $6.56 \pm 0.56$ & $7.89 \pm 0.26$ & $8.20 \pm 1.20$ & 7.52 \\
$\mathrm{Ni}$ & $0.54 \pm 3.38$ & $0.48 \pm 3.50$ & $10.26 \pm 3.50$ & $11.15 \pm 0.20$ & $5.14 \pm 0.12$ & $5.50 \pm 0.05$ & 5.31 \\
$\mathrm{Ag}$ & $0.00 \pm 0.00$ & $0.00 \pm 0.00$ & $0.00 \pm 0.00$ & $0.00 \pm 0.00$ & $0.00 \pm 0.00$ & $0.00 \pm 0.00$ & 0.00 \\
\hline
\end{tabular}

Table 2. Mean concentration of heavy metals in Vernonia Amygdalina of campuses (I, R, U).

\begin{tabular}{cccccccc}
\hline & \multicolumn{7}{c}{ Sample Stations } \\
\hline $\begin{array}{c}\text { Heavy } \\
\text { Metals(mg/kg) }\end{array}$ & I & Control (Ic) & R & Control (Rc) & U & Control (Uc) & Mean \\
\hline $\mathrm{Fe}$ & $14.86 \pm 0.33$ & $15.50 \pm 0.50$ & $12.95 \pm 1.68$ & $13.23 \pm 0.54$ & $18.18 \pm 2.02$ & $19.20 \pm 1.00$ & 15.33 \\
$\mathrm{~Pb}$ & $0.98 \pm 0.11$ & $1.20 \pm 0.20$ & $0.24 \pm 0.64$ & $13.23 \pm 0.54$ & $2.19 \pm 0.74$ & $2.40 \pm 0.50$ & 1.14 \\
$\mathrm{Cd}$ & $0.17 \pm 0.10$ & $0.35 \pm 0.25$ & $0.32 \pm 0.01$ & $0.37 \pm 0.05$ & $0.42 \pm 0.08$ & $0.54 \pm 0.26$ & 0.30 \\
$\mathrm{Cr}$ & $5.92 \pm 0.69$ & $6.15 \pm 0.50$ & $4.88 \pm 0.05$ & $5.10 \pm 0.03$ & $4.04 \pm 0.64$ & $4.50 \pm 0.45$ & 4.95 \\
$\mathrm{Ni}$ & $0.04 \pm 1.42$ & $0.10 \pm 1.60$ & $3.30 \pm 0.88$ & $3.59 \pm 0.10$ & $2.80 \pm 0.53$ & $3.20 \pm 0.10$ & 2.05 \\
$\mathrm{Ag}$ & $0.00 \pm 0.00$ & $0.00 \pm 0.00$ & $0.00 \pm 0.00$ & $0.00 \pm 0.00$ & $0.00 \pm 0.00$ & $0.00 \pm 0.00$ & 0.00 \\
\hline
\end{tabular}

\subsection{Heavy Metal Concentration in Both Soils and Vernonia Amygdalina (Bitter Leaf)}

Total Fe concentration in the soil fell within WHO/FAO safe limit of $300 \mathrm{mg} \cdot \mathrm{kg}^{-1}$ [38]. Concentration of Fe recorded is far below that for soils of Illela Garage in Sokoto State, Nigeria in oil impacted soil of the Niger Delta, and Abattoir soils, in Port Harcourt, Nigeria $[39,40]$. Relatively, high concentration found in RSU is likely due to natural Fe content in soil, especially for both RSU and IAUE, which lie on very similar terrain of soil structure and texture. Averagely, Fe content in both soils and plants is usually high in soil and selected medicinal plants and could emanate from agricultural practices [40,41].

The soil sample result recorded higher $\mathrm{Pb}$ concentration in IAUE (I), followed by Uniport (U), before RSU (R). These results were under similar ranges with those observed in drain soils in Kaduna, Nigeria [42]. These results were though lower than those recorded in earlier works $[40,43]$. These were higher than average concentrations observed in Kano gardens $1.60 \pm 0.53 \mathrm{mg} / \mathrm{kg}$ [44]. This may be likened to the anthropogenic inputs, such as 
vehicle servicing and repair activities, found around these stations. Increased accumulation of $\mathrm{Pb}$ in the human system leads to several medical conditions, including biodiversity loss of lower organisms [45]. Lead $(\mathrm{Pb})$ contaminant may be as a result of adjacent traffic activities and polluted atmospheric precipitation and use of agrochemicals easily assessed by plant absorption [46,47]. Soils affected by $\mathrm{Pb}$ could be ingested by children through the inhalation of dust $\left(\mathrm{PM}_{2 \cdot 5}\right)$ containing $\mathrm{Pb}$, resulting to cardiovascular and respiratory complications $[48,49]$.

The results for $\mathrm{Cd}$ were higher than the lower range limit but lower than the upper range limits in earlier research by Mohammmed and Folorunsho [42] in Makera Drain soils, Kaduna, Nigeria, but absolutely lower than those recorded by Fosu-Mensah et al. [43] in their similar study, but in similar range with the work of Edet and Ukpong [50], on the concentrations of likely toxic metals elements and total hydrocarbon in soils of Niger Delta Region, Nigeria. The concentration of $\mathrm{Cd}$ was higher than those earlier recorded in Pakistani soils [12]. Cadmium (Cd) was mixed with $15 \mathrm{~mL}$ perchloric acid $\left(\mathrm{HClO}_{4}\right)$ and trioxonitrate $\mathrm{V}$ acid $\left(\mathrm{HNO}_{3}\right)$ solution using the respective ratio of 1:4 [3,51]. Cadmium $(\mathrm{Cd})$ concentrations were higher than those found in common ranges of soils $(0.01-0.7 \mathrm{mg} / \mathrm{kg})$ but lower than threshold values $[25,52,53]$. This can be traced to the presence of dumpsite around the study site where abandoned batteries from domestic wastes are disposed. Amini et al. [54] reported best average for Isfahan as $1.79 \mathrm{mg} / \mathrm{kg}$, while Fakhri et al. [25] had average range of $0.42-2.22 \mathrm{mg} / \mathrm{kg}$ in China, which were above those recorded in this research study attributed to soil type, prevalent air pollutants from differential industrial activities, and staple food waste and type. The health implication of elevated $\mathrm{Cd}$ level, especially as an endocrine disruptor and carcinogenicity in humans, cannot be underestimated $[55,56]$. The mean concentrations of $\mathrm{Cd}$ were lower than the threshold limit of $1.4 \mathrm{mg} / \mathrm{kg}$ as prescribed by UK but within the $0.8 \mathrm{mg} / \mathrm{kg}$ level by Dutch's guideline [57]. According to Wuana and Okieimen [8], Cd is bio-persistent but has some toxicological functions, so, once absorbed by any organism, it remains resident for many years. The concentration of $\mathrm{Cd}$ remains a threat from the study results.

The $\mathrm{Cr}$ concentrations showed that all the stations sampled have values below the target value ranges and intervention limits for soils, as well as for plants [58,59]. These were though above those recorded in soils and plants in Pakistan [12]. The results were generally lower than those earlier recorded by Nafiu et al. [60] on the vertical distribution of heavy metals in wastewater-irrigated vegetable garden soils of three West African cities but higher than the lower range limits observed in Calabar [50]. Though the relatively lower concentration of $\mathrm{Cr}$ observed in sample site does not reflect its association with parent granite and ultramafic rocks, as earlier reconfirmed by Mohammed and Folorunsho [42], other human inputs must be of great concern. The primary sources of $\mathrm{Cr}$-contamination are human and industrial activities, such as electroplating processes and poor waste disposal [61]. The higher the concentration of $\mathrm{Cr}$ in IAUE soil types, the higher the probability of more anthropogenic inputs for the study areas. These results are lower than those obtained by Yusuf et al. [62] in Sokoto sampled soils and similar to those obtained by Ezejiofor et al. [63] on the study of environmental metals pollutants load of a densely populated and heavily industrialized commercial city of Aba, Nigeria. These relatively lower values than the standard limits are indication of man-made inputs which must be checked to avoid gradual accumulation and threat to life of both plants and organisms, including humans.

Nickel (Ni) concentration in the study was far lower than those observed in earlier research works $[43,64]$. These results were though lower (Ni) in station I but higher in terms of the upper limit ranges ( $\mathrm{R}$ and I) by Lawal and Audu [44] Kano, Nigeria, and Edet and Ukpong [50] in Calabar. According to Masona et al. [65], wastewater increases heavy metal concentrations in soils, which agrees with the earlier research result of Schmidt [66], that toxic heavy metals, and especially $\mathrm{Ni}$, is commonly found in high concentrations. The most common application of $\mathrm{Ni}$ is as additive in steel and other metal production processes, but the major sources of nickel contamination in the soil are metal plating 
industries, combustion of fossil fuels, and nickel mining and electroplating [67]. Nickel (Ni) can be released into the atmosphere by various processes and industries, such as power plants and trash incinerators, which accumulates on ground surfaces after precipitation reactions, and $\mathrm{Ni}$ is persistent in the atmosphere [8]. The soils recorded relatively higher concentrations of $\mathrm{Ni}$ at the IAUE location than the others, and all the stations sampled have values below the intervention limits for soils, as well as for plants $[59,68]$. This may be due to anthropogenic activities, which are more common around $\mathrm{U}$ and I but not in $\mathrm{R}$, due to site soil properties being near the main capital city, where only vehicular, mechanic workshops, and atmospheric pollutions are likely possible.

According to Saeki et al. [69], the Ag values ranged from 0.27 to $6.89 \mathrm{mg} \mathrm{kg}^{-1}$, which were much higher than the values of the unpolluted soils and also within the range of the results of this study, especially the lower limit of $0.27 \mathrm{mg} / \mathrm{kg}$. The concentrations of Ag were negligible as the range was $0.00-0.00$.

\subsection{Assessment of Pollution Indices and Health Risk Assessment for Heavy Metals in Soils and Bitter Leaf (Vernonia amygdalina)}

\subsubsection{Contamination Factor $(C F)$}

The soil contamination factor $(C F)$ shows the following ranges in Table 3: Fe (0.0004$0.0006)$, very slight contamination; $\mathrm{Pb}(0.22-0.34)$, slight and moderate contamination; $\mathrm{Cd}$ (1.55-4.75), moderate and severe pollution; $\mathrm{Cr}(0.07-0.10), \mathrm{Ni}(0.01-0.15)$, and Ag showed very slight contaminations, whereas, in bitter leaf, Fe (0.27-0.38) was of moderate contamination; $\mathrm{Pb}(0.79-3.27)$ recorded very severe contamination to severe pollution from vehicular emissions; $\mathrm{Cd}(0.83-2.095)$ showed very severe contamination to slight and moderate pollution due to indiscriminate battery disposal around the gardens; $\mathrm{Cr}$ (1.757-2.576) showed very severe contamination to moderate pollution; and $\mathrm{Ni}(0.028-2.197)$ showed very slight contamination to moderate pollution, while Ag recorded very slight contamination. These results were in consonance with those of earlier, similar research studies $[70,71]$. The presence of heavy metal in plant parts have been attributed to reckless use of land, leading to contamination [72,73]. The order of $C F$ for the soil study area in metal composition was $\mathrm{Cd}>\mathrm{Pb}>\mathrm{Cr}>\mathrm{Ni}>\mathrm{Fe}>\mathrm{Ag}$, while, for the bitter leaf, it was $\mathrm{Pb}>$ $\mathrm{Cr}>\mathrm{Cd}>\mathrm{Fe}>\mathrm{Ni}>\mathrm{Ag}$. The trend of heavy metal contamination in both soils and Vernonia amygdalina is shown in Figure 2 below.

Table 3. Contamination factor $(C F)$ for heavy metals in soils and Vernonia amygdalina Delile of campuses (I, R, U).

\begin{tabular}{ccccc}
\hline & \multicolumn{5}{c}{$\begin{array}{c}\text { Sample } \\
\text { Stations }\end{array}$} \\
\hline Heavy Metals (mg/kg) & $\mathbf{I}$ & $\mathbf{R}$ & $\mathbf{U}$ & Mean \\
\hline $\mathrm{Fe}$ & $0.0004(0.310)$ & $0.0006(0.270)$ & $0.0004(0.379)$ & $0.0005(0.320)$ \\
$\mathrm{Pb}$ & $0.3400(3.273)$ & $0.2200(0.790)$ & $0.2800(7.297)$ & $0.2800(3.787)$ \\
$\mathrm{Cd}$ & $1.5500(0.830)$ & $2.3500(1.595)$ & $4.7500(2.095)$ & $2.8833(1.507)$ \\
$\mathrm{Cr}$ & $0.1000(2.576)$ & $0.0700(2.120)$ & $0.0900(1.757)$ & $0.0657(2.151)$ \\
$\mathrm{Ni}$ & $0.0100(0.028)$ & $0.1500(2.197)$ & $0.0800(1.865)$ & $0.0080(1.363)$ \\
$\mathrm{Ag}$ & $<0.001(<0.001)$ & $<0.001(<0.001)$ & $<0.001(<0.001)$ & $<0.001(<0.001)$ \\
\hline
\end{tabular}

Background values: $\mathrm{Fe}=47,000 ; \mathrm{Pb}=20 ; \mathrm{Cd}=0.3 ; \mathrm{Cr}=90 ; \mathrm{Ni}=68 ; \mathrm{Ag}=533, \mathrm{WHO}$ [34]. 


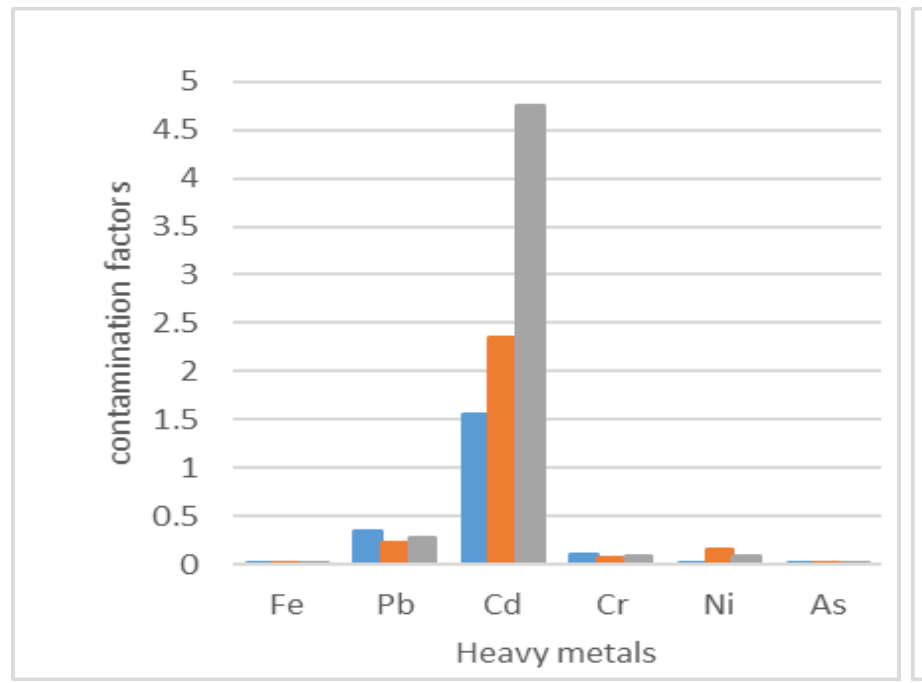

(a) In soils

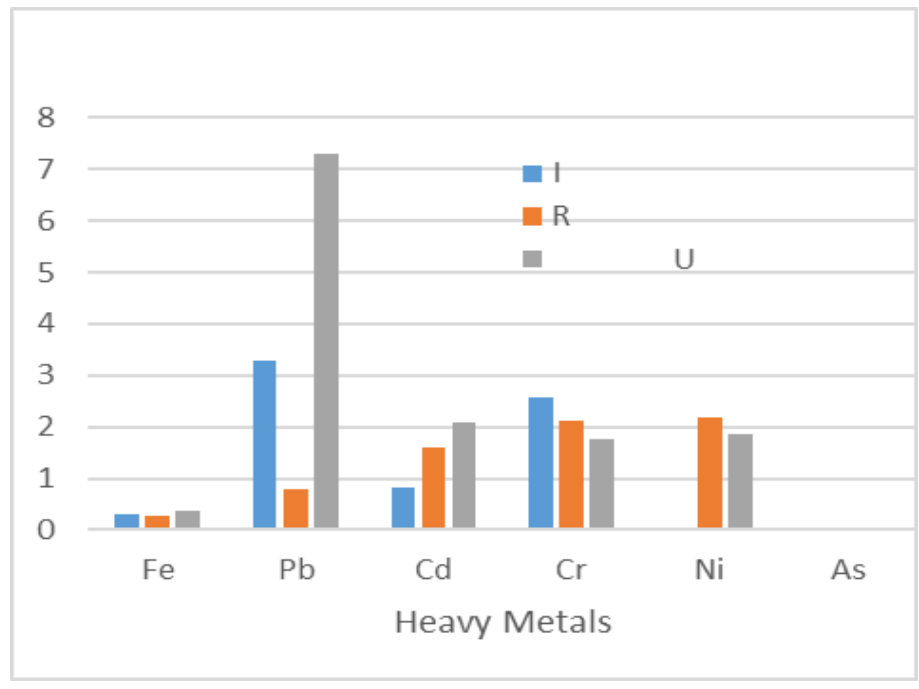

(b) in Vernonia amygdalina

Figure 2. Trend of heavy metal (in $\mathrm{mg} \cdot \mathrm{kg}^{-1}$ ) contamination in soils (a) and Vernonia amygdalina (b).

\subsubsection{Pollution Load Index (PLI)}

Comparatively, the campuses recorded more PLI values in the bitter leaf than in the soil, whose ranges were $0.046-0.08$ for soil and $0.571-1.802$ for bitter leaf, showing that the bitter leaf has more heavy metal retention capacities. PLI indicates deterioration level of soil due to heavy metal accumulation [74]. This may be attributed to both soil-root system flow and anthropogenic input, such as vehicular emissions and open incineration of fossils, which is common around the study region, Niger Delta. Spatially, Uniport had highest PLI values, while the least was in IAUE. This may be connected to the more population, human activities, and water logged soil terrain present in Uniport. The PLI values for almost all the stations and campuses were $<1$, showing baseline levels of low metal pollutions, which indicated permissible soil quality except for Uniport (1.802) and RSU (1.096) in bitter leaf [30]. This was in disagreement with results obtained in similar studies in South Africa, where 95\% of samples had PLI $\geq 1.5$ [75]. This is an indication that the natural concentration has been distorted, hence there being more anthropogenic input in Uniport [76]. This is a threat to the ecosystem, such as water, organisms, and human health, of the area nearest to the stations. The PLI order for heavy metals in the soil was $\mathrm{I}>\mathrm{R}>\mathrm{U}$, while bitter leaf was $\mathrm{I}<\mathrm{R}<\mathrm{U}$.

\subsubsection{Transfer Factor (TF)}

The TF showed reduced concentration with values within range of $0.05-0.092$, as shown in Table 4. The TF for Fe in the bitter leaf was in the range of 0.045 to $0.092 \mathrm{mg} \mathrm{kg}^{-1}$ but was highest in station $\mathrm{U}(0.92)$ and least in $\mathrm{R}(0.45)$; TF for Pb was of 0.05 to $0.39 \mathrm{mg} \mathrm{kg}^{-1}$ range but was highest for $\mathrm{U}(0.39)$ and least in $\mathrm{R}(0.05)$; $\mathrm{Cd}$ ranged from 0.29 to 0.45 but highest in $\mathrm{R}(0.45)$ and least in $\mathrm{U}(0.29)$; Cr ranged from 0.51 to $0.83 \mathrm{mg} \mathrm{kg}^{-1}$ but highest in R (0.83) and least in $\mathrm{U}(0.51)$; and $\mathrm{Ni}$ was ranged $0.08-0.54$, where $\mathrm{U}(0.54)$ was highest and I (0.08) recorded the least. The TF results showed Fe and $\mathrm{Cr}$ were more variable and higher, in tandem with those earlier observed in soils and leaves of bitter leaf in Lagos, Nigeria [13,77]. According to Kumar et al. [78], high values TF indicate low retention capacity. Similarly, TF above 1 indicates hyper-accumulation, especially in soils, according to Eze and Ekanem [79], but values of 0.1 indicated that plant was excluding metals from its tissues, while the TF values of 0.2 indicated the probability of metal contamination by anthropogenic activities [80]. The TF values obtained from studied bitter leaf showed indications of poor accumulation of heavy metals in leaves of the bitter leaf, suggesting affinity of metal to the soil colloids, hence preventing bitter leaf from entry into the metals $[77,81]$. The relatively low $T F$ result obtained for bitter leaf in this 
study is consistent with earlier finding by Ogundele et al. [77], for most plants species. Similarly, $\mathrm{Ni}$ and Fe are plant essential elements, and most plants have the potential to keep them [82]. The occurrence of heavy metals in the ecosystem is catastrophic to plant and organisms, including humans, as a result of their bio-accumulating tendency and toxicity $[83,84]$. Trend of soil heavy metals in plants, pollution index, and transfer factor are illustrated in Figures 2-4, respectively.

Table 4. $C D I_{\text {ing }}$ for the Soils in both adults (A) and children (C).

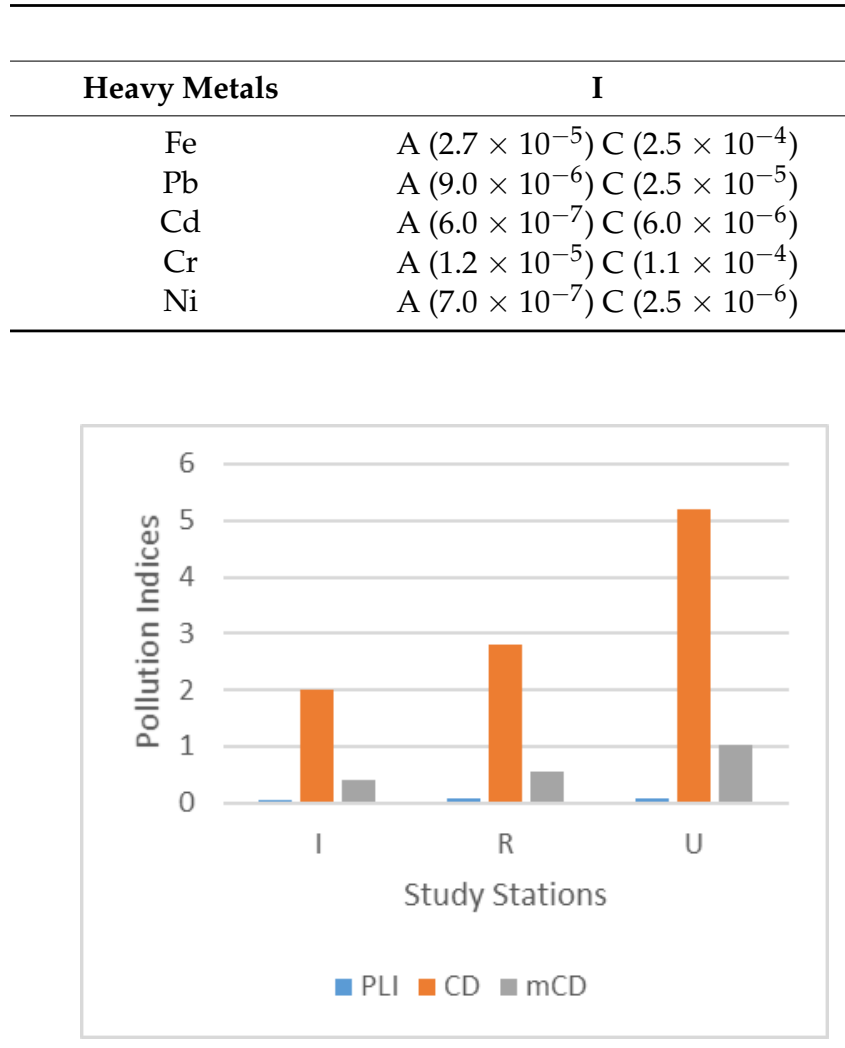

(a) soils

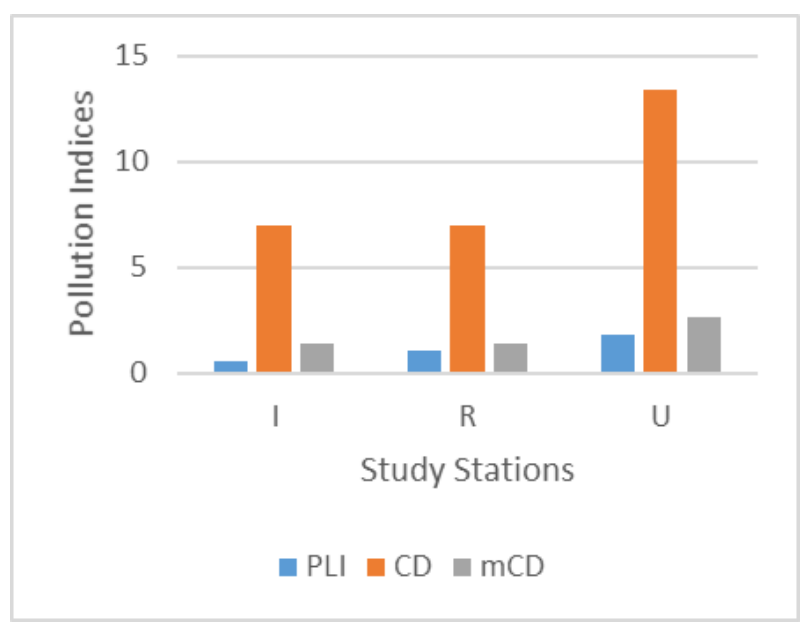

(b) (Vernonia amygdalina Delile)

Figure 3. Pollution indices across study stations in soils (a) and Vernonia amygdalina Delile (b).
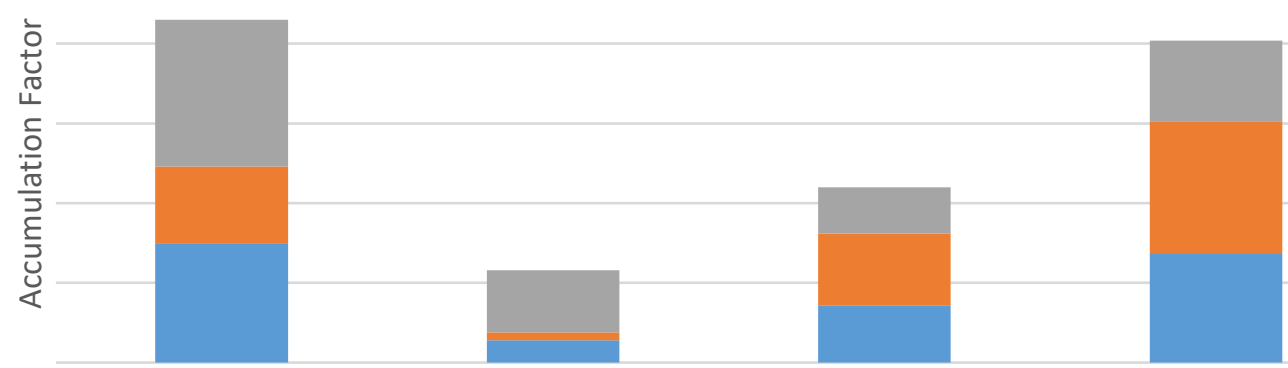
$\mathrm{A}\left(2.7 \times 10^{-5}\right) \mathrm{C}\left(2.5 \times 102^{-4}\right)$ $\mathrm{A}\left(8.0 \times 10^{-6}\right) \mathrm{C}\left(7.2 \times 10^{-5}\right)$ $\mathrm{A}\left(6.0 \times 10^{-6}\right) \mathrm{C}\left(5.6 \times 10^{-5}\right)$ $\mathrm{A}\left(2.0 \times 10^{-6}\right) \mathrm{C}\left(1.8 \times 10^{-5}\right)$ $\mathrm{A}\left(8.0 \times 10^{-6}\right) \mathrm{C}\left(7.6 \times 10^{-5}\right)$ $\mathrm{A}\left(1.1 \times 10^{-5}\right) \mathrm{C}\left(1.0 \times 10^{-4}\right)$ A $\left(1.4 \times 10^{-5}\right) \mathrm{C}\left(1.3 \times 10^{-4}\right)$ A $\left(7.0 \times 10^{-6}\right) \mathrm{C}\left(6.6 \times 10^{-5}\right)$

\section{Sample Stations}


3.2.4. Chronic Daily Intake ( $C D I_{\text {ing }}$ ) for Both Soils and Bitter Leaf in Adults and Children

Table 4 shows that adults have the least $C D I_{\text {ing }}$ values in all the stations compared to those of the children in the agricultural soil. These values were also lower than those recorded for $\mathrm{Ni}, \mathrm{Cr}, \mathrm{Cd}$, and $\mathrm{Pb}$ [85]. The acceptable range for $C D I_{\text {ing }}$ is $10^{-6}-10^{-4}$ which showed that most values obtained for both children and adults were within range, except for station I (Cd and Ni) in adults for the soil. Similarly, Table 5 shows that all the stations recorded $C D I_{\text {ing }}$ values within the acceptable range, according to Liang et al. [85], except for stations $\mathrm{I}(\mathrm{Cd}, \mathrm{Ni}$ in adults and $\mathrm{Ni}$ in children), $\mathrm{R}(\mathrm{Pb}, \mathrm{Cd}$ in adults), and $\mathrm{U}$ ( $\mathrm{Cd}$ in adults) for the bitter leaf samples (Vernonia amygdalina Delile). The chronic daily intake dose was also the heavy metal intake of noxious substances during the exposure period [85]. The chronic and acute health effect on ingestion of $\mathrm{Cd}$ and $\mathrm{Ni}$ as they accumulate in living bodies cannot be over-emphasized $[15,17]$. This may be attributed to anthropogenic inputs as corroborated in similar research studies $[3,86]$.

Table 5. $C D I_{\text {ing }}$ for Vernonia amygdalina in both adults and children.

\begin{tabular}{cccc}
\hline & & Sample Stations & \\
\hline Heavy Metals & I & R & U \\
\hline $\mathrm{Fe}$ & $\mathrm{A}\left(2.0 \times 10^{-5}\right) \mathrm{C}\left(1.9 \times 10^{-4}\right)$ & $\mathrm{A}\left(1.8 \times 10^{-5}\right) \mathrm{C}\left(1.7 \times 10^{-4}\right)$ & $\mathrm{A}\left(2.5 \times 10^{-5}\right) \mathrm{C}\left(2.3 \times 10^{-4}\right)$ \\
$\mathrm{Pb}$ & $\mathrm{A}\left(1.3 \times 10^{-6}\right) \mathrm{C}\left(1.3 \times 10^{-5}\right)$ & $\mathrm{A}\left(3.0 \times 10^{-7}\right) \mathrm{C}\left(3.0 \times 10^{-6}\right)$ & $\mathrm{A}\left(3.0 \times 10^{-6}\right) \mathrm{C}\left(2.8 \times 10^{-5}\right)$ \\
$\mathrm{Cd}$ & $\mathrm{A}\left(2.0 \times 10^{-7}\right) \mathrm{C}\left(2.1 \times 10^{-6}\right)$ & $\mathrm{A}\left(4.0 \times 10^{-7}\right) \mathrm{C}\left(4.1 \times 10^{-6}\right)$ & $\mathrm{A}\left(6.0 \times 10^{-7}\right) \mathrm{C}\left(5.4 \times 10^{-6}\right)$ \\
$\mathrm{Cr}$ & $\mathrm{A}\left(8.0 \times 10^{-6}\right) \mathrm{C}\left(7.6 \times 10^{-5}\right)$ & $\mathrm{A}\left(6.7 \times 10^{-5}\right) \mathrm{C}\left(6.2 \times 10^{-5}\right)$ & $\mathrm{A}\left(5.5 \times 10^{-6}\right) \mathrm{C}\left(5.2 \times 10^{-5}\right)$ \\
$\mathrm{Ni}$ & $\mathrm{A}\left(6.0 \times 10^{-8}\right) \mathrm{C}\left(5.4 \times 10^{-7}\right)$ & $\mathrm{A}\left(4.5 \times 10^{-6}\right) \mathrm{C}\left(4.2 \times 10^{-5}\right)$ & $\mathrm{A}\left(3.8 \times 10^{-6}\right) \mathrm{C}\left(3.6 \times 10^{-5}\right)$ \\
\hline
\end{tabular}

\subsubsection{Health Risk ( $H Q$ and $H I)$}

The hazard quotient $(H Q)$ and hazard index $(H I)$ for both soil and bitter leaf are shown in Table 6; Table 7. This indicated risk from non-carcinogenic effects $(H I>1)$. Additive effects can emanate from the exposure of man to more than one pollutant [87]. The $H I$ for heavy metals in adults and children for the Vernonia amygdalina Delile across the stations for I, R, and U were 1.67, 16.24; 14.46, 83.6; and 8.56, 79.7, respectively. Hazard index $(H I)$ can be used to estimate the likely impacts of these additive effects [88]. The $H I$ were above 1, indicating high risk factor, which was the opposite of results by Xue et al. [89] and Isiuku and Enyoh [87], on the monitoring and modeling of heavy metal contents in vegetables collected from markets in Imo State, Nigeria. The HI obtained were all greater than $1(H I>1)$, showing that negative risks to human health are of immediate concern, as detrimental effects gradually emanate from long-time consumption of these bitter leaf vegetables [89,90]. This may be due to additive effects showing that agricultural soils were contaminated [91]. The $\mathrm{HI}$ index is a useful tool in the assessment of overall noncarcinogenic risk caused by additive effects of toxicants [85]. The highest $H I$ was found in children (222) at station $\mathrm{R}$, while the least was in adults (3.77) at station I. The results calculated for $H I$ in heavy metals were all above safe limits, hence not being risky (all $H I>1)[4,12]$. The overall result is similar to those of Khan et al. [12] in Swat District for agricultural soils and crops, but higher than those earlier reported $[3,13]$. The $H I$ trend for heavy metals is shown in Figure 5. 
Table 6. Hazard Quotient (HQ) for both adults and children in soils.

\begin{tabular}{|c|c|c|c|}
\hline \multirow[b]{2}{*}{ Heavy Metals } & \multicolumn{3}{|c|}{ Sample Stations } \\
\hline & $\mathbf{I}$ & $\mathbf{R}$ & $\mathbf{U}$ \\
\hline $\mathrm{Fe}$ & $\left(5.57 \times 10^{-6}\right)\left(5.14 \times 10^{-4}\right)$ & $\left(7.57 \times 10^{-5}\right)\left(7.14 \times 10^{-4}\right)$ & $\left(5.57 \times 10^{-5}\right)\left(5.14 \times 10^{-4}\right)$ \\
\hline$H Q / H I$ & $\left(1.48 \times 10^{-6}\right)\left(1.42 \times 10^{-5}\right)$ & $\left(3.0 \times 10^{-6}\right)\left(3.2 \times 10^{-6}\right)$ & $\left(3.7 \times 10^{-6}\right)\left(3.7 \times 10^{-6}\right)$ \\
\hline $\mathrm{Pb}$ & $(0.74)(7.14)$ & $(0.49)(4.57)$ & $(0.65)(6.00)$ \\
\hline$H Q / H I$ & $(0.20)(0.20)$ & $(0.02)(0.02)$ & $(0.04)(0.04)$ \\
\hline$\widetilde{C d}$ & $(0.60)(6.00)$ & $(1.00)(9.00)$ & $(2.00)(18.0)$ \\
\hline$H Q / H I$ & $(0.16)(0.17)$ & $(0.04)(0.04)$ & $(0.13)(0.13)$ \\
\hline $\mathrm{Cr}$ & (1.33) (12.3) & $(0.90)(8.33)$ & $(1.23)(11.0)$ \\
\hline$H Q / H I$ & $(0.35)(0.34)$ & $(0.04)(0.04)$ & $(0.08)(0.11)$ \\
\hline $\mathrm{Ni}$ & (1.10) (10.8) & $(22.5)(200)$ & $(11.0)(104)$ \\
\hline$H Q / H I$ & $(0.29)(0.30)$ & $(0.90)(0.90)$ & $(0.74)(0.75)$ \\
\hline
\end{tabular}

Table 7. Hazard Quotient $(H Q)$ for Vernonia Amygdalina in both adults and children), respectively.

\begin{tabular}{cccc}
\hline & \multicolumn{3}{c}{ Sample Stations } \\
\hline Heavy Metals & I & $\mathbf{R}$ & $\mathbf{U}$ \\
\hline $\mathrm{Fe}$ & $\left(4.14 \times 10^{-5}\right)\left(3.86 \times 10^{-4}\right)$ & $\left(3.71 \times 10^{-5}\right)\left(3.43 \times 10^{-4}\right)$ & $\left(5.14 \times 10^{-4}\right)\left(4.71 \times 10^{-4}\right)$ \\
$\mathrm{HQ} / \mathrm{HI}$ & $\left(2.48 \times 10^{-5}\right)\left(2.38 \times 10^{-6}\right)$ & $\left(2.57 \times 10^{-6}\right)\left(4.10 \times 10^{-6}\right)$ & $\left(6.0 \times 10^{-5}\right)\left(5.9 \times 10^{-6}\right)$ \\
$\mathrm{Pb}$ & $(0.11)(1.06)$ & $(0.02)(0.25)$ & $(0.25)(2.29)$ \\
$\mathrm{HQ} / \mathrm{HI}$ & $(0.07)(0.07)$ & $\left(1.38 \times 10^{-3}\right)\left(2.99 \times 10^{-3}\right)$ & $(0.03)(0.03)$ \\
$\mathrm{Cd}$ & $(0.57)(6)$ & $(0.11)(11.7)$ & $(1.71)(15.43)$ \\
$\mathrm{HQ} / \mathrm{HI}$ & $(0.34)(0.37)$ & $\left(7.61 \times 10^{-3}\right)(0.14)$ & $(0.20)(0.19)$ \\
$\mathrm{Cr}$ & $(0.9)(8.33)$ & $(0.51)(0.08)$ & $(0.07)(0.07)$ \\
$\mathrm{HQ} / \mathrm{HI}$ & $(10)(9.8)$ & $(7)(65)$ & $(6)(56.3)$ \\
$\mathrm{Ni}$ & $(0.09)(0.85)$ & $(0.48)(0.78)$ & $(0.71)(0.71)$ \\
$\mathrm{HQ} / \mathrm{HI}$ & $(0.05)(0.05)$ &
\end{tabular}

$\mathrm{HI}$ in Vernonia amygdalina for adult and children(I) is 1.67, 16.24; (R) is 14.46, 83.6; (U) is 8.56, 79.7.

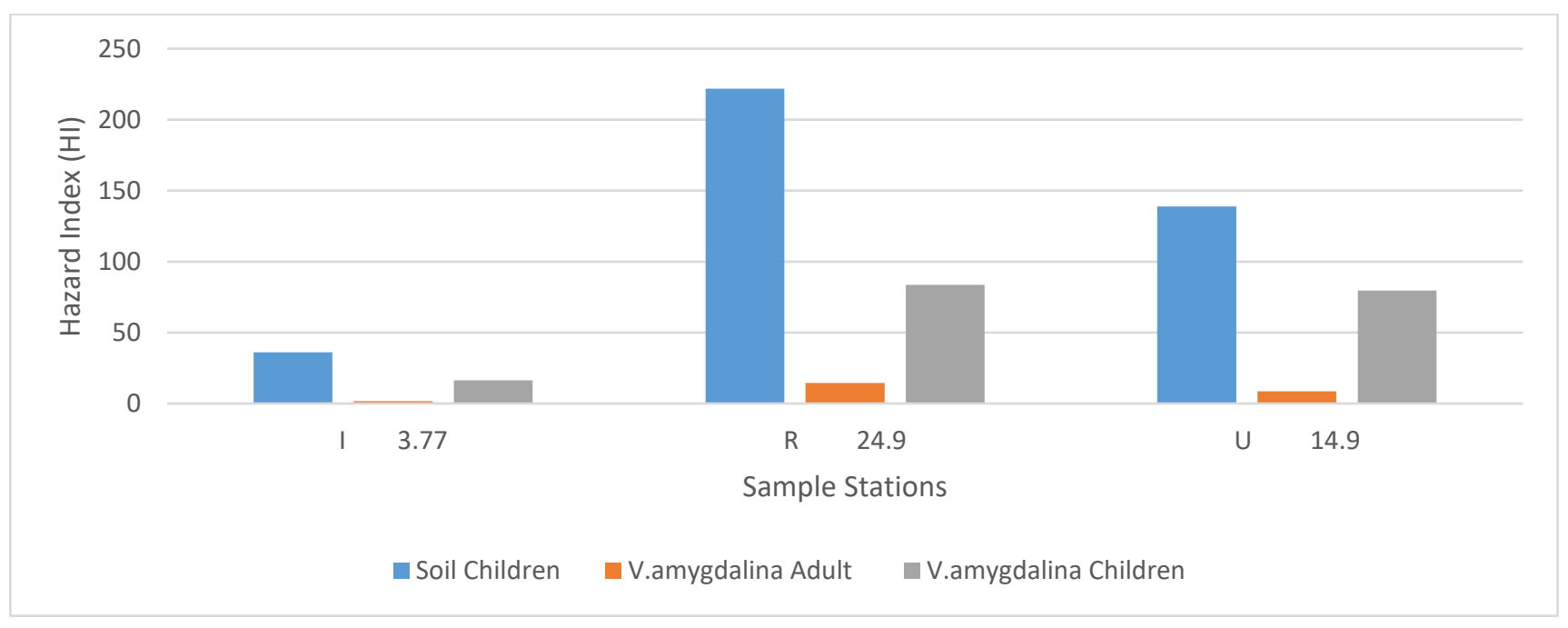

Figure 5. Spatial Hazard Index trend for both soil and Vernonia amygdalina.

The total hazard index (THI or TTHQ) in the stations were all greater than 1, suggesting that the heavy metal health risks of exposure through bitter leaf consumption from these soils were comparatively above safe limits, hence being of great risk and negative to earlier research studies on different vegetable species [81,91]. THI was high and of great risk probably due to increased use of land for agricultural purposes introducing foreign agents, such as fertilizers and pesticides. 


\subsubsection{Carcinogenic Risk Analysis}

Cancer in humans can be increased by heavy metals, such as $\mathrm{Pb}, \mathrm{Cd}, \mathrm{Cr}$, and $\mathrm{Ni}$, especially prolonged exposure to low concentrations of these toxic metals [92]. Therefore, using $\mathrm{Pb}, \mathrm{Cr}, \mathrm{Cd}$, and $\mathrm{Ni}$ as carcinogens, the exposure of the residents were assessed based on the CDI values. The carcinogenic risk assessment for adults and children for both soil and Vernonia amygdalina is shown in Table 8; Table 9. Heavy metals whose ILCR is $<1.0 \times 10^{-6}$ are assumed insignificant; hence, the cancer risk could be neglected, but, above $1.0 \times 10^{-4}$, it is taken as a harmful and troublesome cancer risk result. This study revealed that $\mathrm{Pb}$ (soil) has the highest chances of cancer risks, especially in children (mean ILCR, $2.0 \times 10^{-2}$ ), while $\mathrm{Cd}$ has the least (mean $I L C R, 3.36 \times 10^{-5}$ ). For Vernonia amygdalina, $\mathrm{Pb}$ has the highest chances of cancer risks (mean ILCR, $2.45 \times 10^{-3}$ ), while Cd had the least (mean $I L C R, 3.362 \times 10^{-5}$ ). The implication of these results was that there is potential risk of cancer emanating from the impact of contaminants through the ingestion route by accumulation in both soil and Vernonia amygdalina Delile.

Table 8. Incremental Lifetime Cancer Risk (ILCR) in soil for children and adults.

\begin{tabular}{cccc}
\hline & & Sample Stations & U \\
\hline Heavy Metals & I & R & $(0)(0)$ \\
$\mathrm{Fe}$ & $(0)(0)$ & $(0)(0)$ & $\left(9.41 \times 10^{-4}\right)\left(8.47 \times 10^{-3}\right)$ \\
$\mathrm{Pb}$ & $\left(1.06 \times 10^{-3}\right)\left(2.94 \times 10^{-3}\right)$ & $\left(2.63 \times 10^{-6}\right)\left(6.37 \times 10^{-5}\right)$ & $\left(5.26 \times 10^{-6}\right)\left(4.74 \times 10^{-5}\right)$ \\
$\mathrm{Cd}$ & $\left(1.58 \times 10^{-6}\right)\left(1.58 \times 10^{-5}\right)$ & $\left(1.6 \times 10^{-5}\right)\left(1.52 \times 10^{-4}\right)$ & $\left(2.26 \times 10^{-5}\right)\left(2.2 \times 10^{-4}\right)$ \\
$\mathrm{Cr}$ & $\left(2.4 \times 10^{-5}\right)\left(2.2 \times 10^{-4}\right)$ & $\left(1.54 \times 10^{-5}\right)\left(1.43 \times 10^{-4}\right)$ & $\left(7.69 \times 10^{-6}\right)\left(7.25 \times 10^{-5}\right)$ \\
$\mathrm{Ni}$ & $\left(7.69 \times 10^{-7}\right)\left(2.75 \times 10^{-6}\right)$ & $\left(7.69 \times 10^{-6}\right)$ & \\
\hline
\end{tabular}

$\mathrm{CSF}\left(\mathrm{mg} \cdot \mathrm{kg}^{-1} \cdot \text { day }^{-1}\right)^{-1} ; \mathrm{Fe}=0.0 ; \mathrm{Pb}=0.0085 ; \mathrm{Cd}=0.38 ; \mathrm{Cr}=0.5 ; \mathrm{Ni}=0.91$ : Permissible limit for single element $=10^{-6}<10^{-4}$

Table 9. Incremental Lifetime Cancer Risk (ILCR) for Vernonia amygdalina Delile in both adults and children.

\begin{tabular}{cccc}
\hline & & Sample Stations & U \\
\hline Heavy Metals & I & R & $(0)(0)$ \\
$\mathrm{Fe}$ & $(0)(0)$ & $(0)(0)$ & $\left(3.53 \times 10^{-4}\right)\left(2.8 \times 10^{-5}\right)$ \\
$\mathrm{Pb}$ & $\left(1.53 \times 10^{-4}\right)\left(1.53 \times 10^{-3}\right)$ & $\left(3.53 \times 10^{-5}\right)\left(3.53 \times 10^{-4}\right)$ & $\left(1.58 \times 10^{-6}\right)\left(1.42 \times 10^{-5}\right)$ \\
$\mathrm{Cd}$ & $\left(5.26 \times 10^{-7}\right)\left(5.53 \times 10^{-6}\right)$ & $\left(1.05 \times 10^{-6}\right)\left(1.08 \times 10^{-5}\right)$ & $\left(1.1 \times 10^{-5}\right)\left(1.04 \times 10^{-4}\right)$ \\
$\mathrm{Cr}$ & $\left(1.6 \times 10^{-5}\right)\left(1.52 \times 10^{-4}\right)$ & $\left(1.34 \times 10^{-4}\right)\left(1.24 \times 10^{-4}\right)$ & $\left(4.18 \times 10^{-6}\right)\left(3.96 \times 10^{-5}\right)$ \\
$\mathrm{Ni}$ & $\left(6.59 \times 10^{-8}\right)\left(5.93 \times 10^{-7}\right)$ & $\left(4.94 \times 10^{-6}\right)\left(4.62 \times 10^{-5}\right)$ & \\
\hline
\end{tabular}

\subsubsection{Enrichment Factor (EF)}

All the stations in both soil and bitter leaf showed extremely high EF as all were greater than 40 but were relatively higher in the bitter leaf samples than as found in the soils, as shown in Table 10. For the soil samples, Uniport (U) recorded the highest in $\mathrm{Cd}$ $(11,302)$, but $\mathrm{Pb}(18,709)$ in bitter leaf was highest in the same, Uniport. The least EF in soil was found in $\mathrm{Ni}$ (I) and also for the bitter leaf (I). These values were lower than those of Edith-Etakah et al. [93], on the soils of the Kette-Batouri Region, Eastern Cameroon. The highest $\mathrm{EF}$ of $\mathrm{Cd}$ (soil) and $\mathrm{Pb}$ (bitter leaf) in the same station is an indication of increase pollution potentials and more activities within the location, such as high vehicular and pollutant emissions, likely to endanger human health, though not as effective as those recorded earlier in separate studies on heavy metals through three exposure routes [91]. 
Table 10. Enrichment Factors (EF) for the soil and Vernonia amygdalina samples.

\begin{tabular}{ccccc}
\hline \multicolumn{5}{c}{ Sample Stations } \\
\hline Heavy Metals & I & R & U & Mean \\
\hline $\mathrm{Fe}$ & - & - & - & - \\
$\mathrm{Pb}$ & $191(10,229)$ & $88(2821)$ & $157(18,709)$ & $145(10,586)$ \\
$\mathrm{Cd}$ & $3683(2594)$ & $4057(5696)$ & $11,302(5372)$ & $6347(4554)$ \\
$\mathrm{Cr}$ & $232(8049)$ & $113(7570)$ & $209(4504)$ & $185(6708)$ \\
$\mathrm{Ni}$ & $19(88)$ & $260(7848)$ & $180(4783)$ & $153(4240)$ \\
\hline
\end{tabular}

\subsubsection{Ecological Risk Factor $\left(E_{r} F\right)$ and Risk Index $(R I)$}

The results of $E r F$ are shown in Table 11 for soil and bitter leaf, respectively. The $E_{r} F$ and $R I$ in soils were all, respectively, less than 40 but not as much as $150\left(40<E_{r} F\right.$ or $R I<150$ ), showing low risk factor, but the bitter leaf samples had moderate risk for $\mathrm{Cd}$ in station $\mathrm{R}$ and $\mathrm{U}$, at 47.85 and 62.85 , respectively. The $E r F$ showed relatively lower values in all the stations in soils for the $\mathrm{Pb}, \mathrm{Cd}, \mathrm{Cr}$, and $\mathrm{Ni}$ compared to those of the bitter leaf except station $\mathrm{U}(\mathrm{Cd}, 41.7$ in soil) and very low in bitter leaf for I $(\mathrm{Ni}, 0.14)$. The higher values of $E r F$ were found in soil within the range of $40 \leq E r F<80$ (U, Cd-41.7) and in bitter leaf for $\mathrm{Cd}(\mathrm{R}-47.85, \mathrm{U}-62.85)$, hence requiring further studies, as it shows both soil and bitter leaf samples were of moderate potential ecological risks, as agreed upon in other related similar studies $[94,95]$. These values were relatively lower than those recorded in abandoned and active dumpsites in Lagos of range, 43.86-732.4 [23].

Table 11. Ecological Risk Factor $\left(E_{r} F\right)$ and Potential Ecological Risk Factor $(R I)$ for the soil and Vernonia amygdalina Delile.

\begin{tabular}{ccccc}
\hline \multicolumn{5}{c}{ Sample Stations } \\
\hline Heavy Metals & $\mathbf{I}$ & $\mathbf{R}$ & $\mathbf{U}$ & Mean \\
\hline $\mathrm{Fe}$ & - & - & - & - \\
$\mathrm{Pb}$ & $1.70(16.37)$ & $1.10(3.95)$ & $1.400(36.49)$ & $1.40(18.94)$ \\
$\mathrm{Cd}$ & $46.50(24.90)$ & $70.50(47.85)$ & $142.5(62.85)$ & $86.5(45.20)$ \\
$\mathrm{Cr}$ & $0.20(5.15)$ & $0.14(4.24)$ & $0.180(3.51)$ & $0.17(4.30)$ \\
$\mathrm{Ni}$ & $0.05(0.14)$ & $0.75(10.99)$ & $0.400(9.33)$ & $0.40(6.82)$ \\
$\mathrm{RI}$ (Risk Index) & $48.45(46.56)$ & $72.49(67.03)$ & $144.5(112.18)$ & $88.48(75.26)$ \\
\hline
\end{tabular}

\subsection{Statistical Analysis and Inter-Metal Correlation}

The respective mean $(\mathrm{mg} / \mathrm{kg})$, median $(\mathrm{mg} / \mathrm{kg})$, minimum $(\mathrm{mg} / \mathrm{kg})$, maximum $(\mathrm{mg} / \mathrm{kg})$, and standard deviation for $\mathrm{Fe}, \mathrm{Pb}, \mathrm{Cd}, \mathrm{Cr}$, and $\mathrm{Ni}$ were 15.33, 14.86, 12.95, $18.18,2.65 ; 1.14,0.98,0.24,2.19,0.99 ; 0.90,0.319,0.17,0.42,0.13 ; 4.95,4.88,4.04,5.92,0.94$; and 2.05, 2.80, 0.04, 3.30, and 1.75, as shown in Table 12. Figure 6 shows the parametric and spatial variations in heavy metals, and the three locations of 1, 2, 3, 4, 5, 6 represent $\mathrm{Fe}, \mathrm{Pb}$, $\mathrm{Cd}, \mathrm{Cr}, \mathrm{Ni}$, and $\mathrm{Ag}$, respectively. 
Table 12. Statistics of $\mathrm{Fe}, \mathrm{Pb}, \mathrm{Cd}, \mathrm{Cr}$, and $\mathrm{Ni}$ in both Vernonia Amygdalina Delile and soils in the study stations.

\begin{tabular}{cccccc}
\hline & & & \multicolumn{3}{c}{$\begin{array}{c}\text { Statistics } \\
\text { (Bitter Leaf) }\end{array}$} \\
\hline Heavy Metals (mg/kg) & Mean & Median & Min & Max & SD \\
\hline $\mathrm{Fe}$ & 15.33 & 14.86 & 12.95 & 18.18 & 2.65 \\
$\mathrm{~Pb}$ & 1.14 & 0.98 & 0.24 & 2.19 & 0.99 \\
$\mathrm{Cd}$ & 0.90 & 0.319 & 0.17 & 0.42 & 0.13 \\
$\mathrm{Cr}$ & 4.95 & 4.88 & 4.04 & 5.92 & 0.94 \\
$\mathrm{Ni}$ & 2.05 & 2.80 & 0.04 & 3.30 & 1.75 \\
\hline & & & & Statistics (soil) & \\
& Mean & Median & Min & Max & SD \\
$\mathrm{Fe}$ & 22.21 & 19.71 & 19.70 & 27.24 & 4.35 \\
$\mathrm{~Pb}$ & 5.59 & 5.60 & 4.35 & 6.80 & 1.23 \\
$\mathrm{Cd}$ & 0.86 & 0.71 & 0.46 & 1.42 & 0.50 \\
$\mathrm{Cr}$ & 7.52 & 7.89 & 5.91 & 8.77 & 1.47 \\
$\mathrm{Ni}$ & 5.31 & 5.14 & 0.54 & 10.26 & 4.86 \\
\hline
\end{tabular}

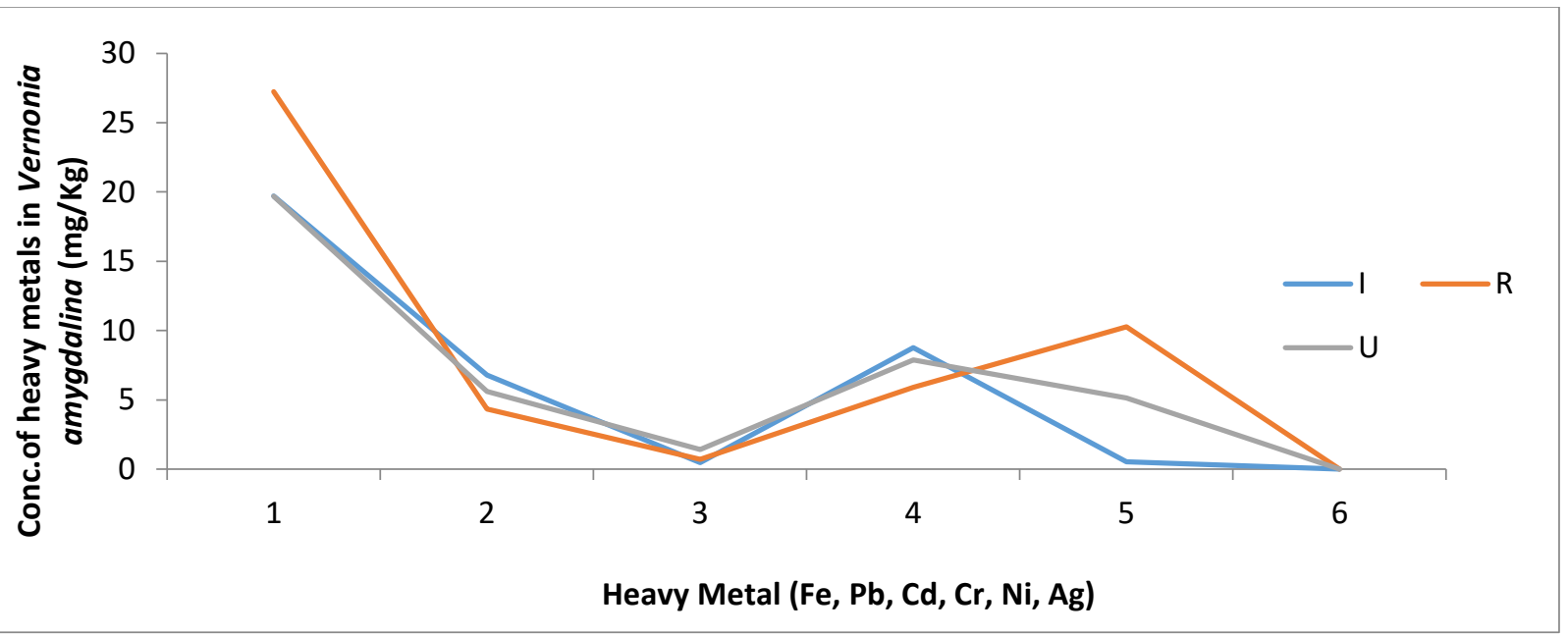

Figure 6. Spatial variation of heavy metals in Vernonia amygdalina.

One-way ANOVA result showed that there were no significant differences and correlation (f-ratio $=0.05 ; p$-value $=0.95 p<0.05$ ) in the levels of heavy metals in the study soils of the stations. Similarly, $t$-test was used to compare the heavy metal contents of both garden soil and Vernonia amygdalina $(\mathrm{t}=-0.73 ; p$-value $=0.24)$, which also gave no significant difference between the levels of the soil and Vernonia amygdalina Delile, indicating that soil-plant heavy metal uptake was efficient similar to that of Fakhri et al. [25], on probabilistic risk assessment of $\mathrm{Pb}$ and $\mathrm{Cd}$ in Iran. There was no significant correlation existing within the three study stations, both in soil and bitter leaf samples, in contrast to the significant positive correlation in greenhouses [96]. The negative values for metals gave credence to the non-contaminated soil and bitter leaf, similar to earlier research on pollution status of heavy metals and risks within sediments in China [97]. The concentration of Fe in soil and Vernonia amygdalina Delile were found to be of strong negative correlation using 2 -tailed Pearson's Product Correlation coefficient, $\mathrm{r}(16)=-0.78, p<0.05$. Conversely, $\mathrm{Pb}$ and $\mathrm{Cr}$ recorded weak positive correlations of $\mathrm{r}(16)=0.39, p<0.136$ and $\mathrm{r}(16)=0.36$, $p=0.167$, indicating that both heavy metals increase in concentration simultaneously, though weak but not significant at $p<0.05$, respectively. Similarly, the soil and Vernonia amygdalina recorded strong positive correlations for $\mathrm{Cd}$ and $\mathrm{Ni}$ of $\mathrm{r}(16)=0.92, p<0.000$ 
and $r(16)=0.92, p<0.00$, and significant at $p<0.05$, respectively, meaning that, as the concentrations of $\mathrm{Cd}$ and $\mathrm{Ni}$ increases, so does that of the vegetable.

\section{Conclusions}

This study showed that the studied soils and Vernonia amygdalina Delile plant recorded some heavy metal concentrations that require adequate monitoring to avoid values above permissible limits. The health risk index for $\mathrm{Cd}$ showed risk from non-carcinogenic effects as almost all the stations recorded $\mathrm{HI}>1$ values for the plant and Vernonia amygdalina. This was due to projected bioaccumulation and $C D I_{\text {ing }}$ for $\mathrm{Cd}$. The ecological risks (ErF and $E F$ ) recorded for $\mathrm{Cd}$ in bitter leaf poses a potential threat. The increasing population explosion is a threat due to limited food supply; hence, garden farming must be encouraged, especially by the tolerable heavy metal levels found within these university campuses. The study showed that there is potential risk of cancer from the contaminants through the ingestion route due to accumulation in both soil and Vernonia amygdalina Delile, though highest chances in children (mean ILCR, $2.07 \times 10^{-2}$ ), but Cd has the least (mean ILCR, $3.36 \times 10^{-5}$ ). For Vernonia amygdalina, $\mathrm{Pb}$ has the highest chances of cancer risks (mean $I L C R, 2.45 \times 10^{-3}$ ), while $C d$ has the least (mean ILCR, $3.362 \times 10^{-5}$ ).

There is the ardent need for regular monitoring to ascertain optimum concentration which may have concomitant negative effect on plant and humans. Similarly, the need to monitor the anthropogenic activities around these areas, especially air pollution due to the illegal crude oil refining, is of necessity. The number of heavy metals considered in this work may not be enough to draw vivid conclusion on heavy metal impact; hence, others, such as copper, arsenic, cobalt, zinc, etc., should also be monitored. The absorption of heavy metals through other routes other than ingestion should be evaluated.

Author Contributions: Conceptualization, W.A.I. and K.O.; methodology, W.A.I. software, W.A.I. validation, W.A.I. and K.O.; formal analysis, W.A.I.; investigation, W.A.I.; resources, K.T.; data curation, W.A.I.; writing-original draft preparation, W.A.I.; writing-review and editing, K.O. and K.T.; visualization, W.A.I.; supervision, K.T.; project administration, W.A.I. and K.O.; funding acquisition, K.T. All authors have read and agreed to the published version of the manuscript.

Funding: This research was supported by Prince of Songkla University and Ministry of Higher Education, Science, Research and Innovation under the Reinventing University Project (Grant Number REVPD64013).

Institutional Review Board Statement: Not applicable.

Informed Consent Statement: Not applicable.

Data Availability Statement: Not applicable.

Acknowledgments: This study is supported by the Prince of Songkla University (PSU) Presidents Scholarship and the Ministry of Higher Education, Thailand. We are very grateful for this scholarship grant (Grant NO: REVPD64013).

Conflicts of Interest: The authors declare no conflict of interest.

\section{References}

1. Shah, M.T.; Shaheen, B.; Khan, S. Pedo and biogeochemical studies of mafic and ultramafic rocks in the Mingora and Kabal areas, Swat, Pakistan. Environ. Earth Sci. 2010, 60, 1091-1102. [CrossRef]

2. Sekomo, C.B.; Nkurang, E.; Sousseau, D.P.; Lens, P.N. Fate of heavy metals in an urban natural wetland: The Nyabugogo Swamp (Rwanda). Water Air Soil Pollut. 2011, 214, 321-333. [CrossRef]

3. Khan, S.; Rehman, S.; Khan, A.Z.; Khan, M.A.; Shah, M.T. Soils and vegetables enrichment with heavy metals from geological sources in Gilgit, northern Pakistan. Ecotoxicol. Environ. Saf. 2010, 73, 1820-1827. [CrossRef]

4. Muhammad, S.; Shah, M.T.; Khan, S. Health risk assessment of heavy metals and their source apportionment in drinking water of Kohistan region, northern Pakistan. Microchem. J. 2011, 98, 334-343. [CrossRef]

5. Koller, M.; Saleh, H.M. Introductory chapter: Introducing heavy metals. In Heavy Metals; Hosam El-Din, M., Saleh, R., Aglan, F., Eds.; IntechOpen: London, UK, 2018; Available online: https:/ / www.intechopen.com/books/heavy-metals/introductorychapter-introducing-heavy-metals (accessed on 20 August 2021). 
6. Singh, M.R. Impurities-Heavy Metals: IR Perspective; Indian Pharmacopoeia Commission: Ghaziabad, India, 2007. Available online: http:/ / www.usp.org/pdf/EN/meeting/asMeetingIndia/2008Session4track1.pdf (accessed on 26 September 2021).

7. Zhang, M.K.; Liu, Z.Y.; Wang, H. Use of single extraction methods to predict bioavailability of heavy metals in polluted soils to rice. Commun. Soil Sci. Plant Anal. 2010, 41, 820-831. [CrossRef]

8. Wuana, R.A.; Okieimen, F.E. Heavy metals in contaminated soils: A Review of sources, chemistry, risks and best available strategies for remediation. Int. Sch. Res. Not. 2011, 2011, 402647. [CrossRef]

9. Khan, S.; Cao, Q.; Zheng, Y.M.; Huang, Y.Z.; Zhu, Y.C. Health risks of heavy metals in contaminated soils and food crops irrigated with wastewater in Beijing, China. Environ. Pollut. 2008, 152, 686-692. [CrossRef]

10. Evanko, C.R.; Dzombak, D.A. Remediation of Metals-Contaminated Soils and Groundwater; Ground-Water Remediation Technologies Analysis Center: Pittsburgh, PA, USA, 1997.

11. Kafayatullah, Q.; Shah, M.T.; Irfan, M. Biogeochemical and environmental study of the chromite-rich ultramafic terrain of Malakand area, Pakistan. Environ. Geol. 2001, 40, 1482-1486.

12. Khan, K.; Lu, Y.; Khan, H.; Ishtiaq, M.; Khan, S.; Waqas, M.; Wei, L.; Wang, T. Heavy metals in agricultural soils and crops and their health risks in Swat District, northern Pakistan. Food Chem. Toxicol. 2013, 58, 449-458. [CrossRef]

13. Jan, F.A.; Ishaq, M.; Khan, S.; Ihsanullah, I.; Ahmad, I.; Shakirullah, M. A comparative study of human health risks via consumption of food crops grown on wastewater irrigated soil (Peshawar) and relatively clean water irrigated soil (lower Dir). J. Hazard. Mater. 2010, 179, 612-621. [CrossRef] [PubMed]

14. Yang, Z.; Yi, Y.; Zhang, S. Ecological risk assessment of heavy metals in sediment and human health risk assessment of heavy metals in fishes in the middle and lower reaches of the Yangtze River basin. Environ. Pollut. 2011, 159, $2575-2585$.

15. Sun, C.; Bi, C.; Chen, Z.; Wang, D.; Zhang, C.; Sun, Y.; Yu, Z.; Zhou, D. Assessment on environmental quality of heavy metals in agricultural soils of Chongming Island, Shanghai City. J. Geogr. Sci. 2010, 20, 135-147. [CrossRef]

16. Nordberg, G.; Jin, T.; Bernard, A.; Fierens, S.; Buchet, J.P.; Ye, T.; Kong, Q.; Wang, H. Low bone density and renal dysfunction following environmental cadmium exposure in China. AMBIO 2002, 31, 478-481. [CrossRef] [PubMed]

17. Turkdogan, M.K.; Fevzi, K.; Kazim, K.; Ilyas, T.; Ismail, U. Heavy metal in soil, vegetables and fruits in the endemic upper gastrointestinal cancer region of Turkey. Environ. Toxicol. Pharmacol. 2003, 13, 175-179. [CrossRef]

18. Sun, F.F.; Wang, F.H.; Wang, X.; He, W.; Wen, D.; Wang, Q.F.; Liu, X.X. Soil threshold values of total and available cadmium for vegetable growing based on field data in Guangdong Province, south China. J. Sci. Food Agric. 2013, 93, 1967-1973. [CrossRef] [PubMed]

19. Sinha, S.; Gupta, A.K.; Bhatt, K.; Pandey, K.; Rai, U.; Singh, K.P. Distribution of metals in the edible plants grown at Jajmau, Kanpur (India) receiving treated tannery waste water, relation with physicochemical properties of the soil. Environ. Monit. Assess. 2006, 115, 1-22. [CrossRef] [PubMed]

20. Echem, O.G.; Kabari, L.G. Heavy metal content in bitter leaf (Vernonia amygdalina) grown along heavy traffic routes in Port Harcourt. Agric. Chem. 2013, 12, 201-210.

21. Radwan, M.A.; Salama, A.K. Market basket survey for some heavy metals in Egyptian fruits and vegetables. Food Chem. Toxicol. 2006, 44, 1273-1278. [CrossRef]

22. Echem, O.G. Analysis of heavy metals (Lead Pb, Cadmium Cd, Chromium Cr, and Cobalt Co) content of cassava (Manihot esculenta crantz) cultivated on oil polluted soil in Ogoni land, Nigeria. Int. J. Pure Appl. Sci. 2010, 3, $23-30$.

23. Odukoya, A.M. Contamination assessment of toxic elements in the soil within and around two dumpsites in Lagos, Nigeria. Ife J. Sci. 2015, 17, 351-361.

24. Edori, O.S.; Kpee, F. Index models assessment of heavy metal pollution in soils within selected abbattoirs in port harcourt, Rivers State, Nigeria. Singap. J. Sci. Res. 2017, 7, 9-15.

25. Fakhri, Y.; Khaneghah, A.M.; Conti, G.O.; Ferrante, M.; Khezri, A.; Darvishi, A.; Ahmadi, M.; Hasanzadeh, V.; Rahimizadeh, A.; Keramati, H.; et al. Probabilistic risk assessment (Monte Carlo simulation method) of $\mathrm{Pb}$ and $\mathrm{Cd}$ in the onion bulb (Alliumcepa) and soil of Iran. Environ. Sci. Pollut. Res. 2018, 25, 30894-30906. [CrossRef] [PubMed]

26. Welz, B.; Sperling, M. Atomic Absorption Spectrometry, 3rd ed.; John Wiley \& Sons: Weinheim, Germany, 1999.

27. Adesodun, J.K.; Atayese, M.O.; Agbaje, T.; Osadiaye, B.A.; Mafe, O.; Soretire, A.A. Phytoremediation potentials of sunflowers (Tithonia diversifolia andHelianthusannuus) for metals ins oils contaminated with zinc and lead nitrates. Water Air Soil Pollut. 2010, 207, 195-201. [CrossRef]

28. Harikumar, P.S.; Nasir, U.P.; Rahman, M.P.M. Distribution of heavy metals in the Core Sediments of Tropical Wetland System. Int. J. Environ. Sci. Technol. 2009, 6, 225-232. [CrossRef]

29. Wang, H.H.; Li, L.Q.; Wu, X.M.; Pan, G.X. Distribution of $\mathrm{Cu}$ and $\mathrm{Pb}$ in particle size fractions of urban soils from different city zones of Nanjing, China. J. Environ. Sci. 2006, 18, 482-487.

30. Tomlinson, D.L.; Wilson, J.G.; Harris, C.R.; Jeffrey, D.W. Problems in the assessment of heavy-metal levels in estuaries and the formation of a pollution index. Helgol. Meeresunters 1980, 33, 566-575. [CrossRef]

31. Sutherland, R.A. Bed sediment-associated trace metals in an urban stream, Oahu, Hawaii. Environ. Geol. 2000, 39, 611-627. [CrossRef]

32. Hakanson, L. An ecological risk index for aquatic pollution control: A sedimentological approach. Water Res. 1980, 14, 975-1001. [CrossRef] 
33. WHO, World Health Organization. Evaluation of Certain Food Additives and Contaminants. In Forty-First Report of the Joint FAO/WHO Expert Committee on Food Additives; WHO Technical Series; WHO: Geneva, Switzerland, 1993 ; p. 837.

34. USEPA. Environmental Protection Agency. Integrated Risk Information System. 2000. Available online: http://cfpub.epa.gov/ ncea/iris/compare.cfm (accessed on 20 August 2021).

35. IBGE. Censo Agropecuário 2006; Instituto Brasileiro de Geografia e Estatística: Rio de Janeiro, Brazil, 2006.

36. Gržetić, I.; Ghariani, A.R.H. Potential health risk assessment for soil heavy metal contamination in the central zone of Belgrade (Serbia). J. Serb. Chem. Soc. 2008, 73, 923-934. [CrossRef]

37. Tepanosyan, G.; Maghakyan, N.; Sahakyan, L.; Saghatelyan, A. Heavy metals pollution levels and children health risk assessment of Yerevan kindergartens soils. Ecotoxicol. Environ. Saf. 2017, 142, 257-265. [CrossRef]

38. Chiroma, T.M.; Ebewele, R.O.; Hymore, F.K. Comparative assessment of heavy metal levels in soil, vegetables and urban grey waste water used for irrigation in Yola and Kano. Int. Refereed J. Eng. Sci. 2014, 3, 1-9.

39. Edori, O.S.; Iyama, W.A. Assessment of physicochemical parameters of soils from selected abattoirs in Port Harcourt, Rivers state, Nigeria. J. Environ. Anal. Chem. 2017, 4, 194-199. [CrossRef]

40. Kacholi, D.S.; Sahu, M. Levels and health risk assessment of heavy metals in soil, water, and vegetables of dares salaam, Tanzania. J. Chem. 2018, 2018, 1402674. [CrossRef]

41. Tasrina, R.C.; Rowshon, A.; Mustafizur, A.M.R.; Rafiqul, I.; Ali, M.P. Heavy metals contamination in vegetables and its growing soil. J. Environ. Analytical. Chem. 2015, 2, 142-147.

42. Mohammed, S.A.; Folorunsho, J.O. Heavy metals concentration in soil and Amaranthusretroflexus grown on irrigated farmlands in the Makera Area, Kaduna, Nigeria. J. Geogr. Reg. Plan. 2015, 8, 210-217. [CrossRef]

43. Fosu-Mensah, B.Y.; Addae, E.; Yirenya-Tawiah, D.; Nyame, F. Heavy metals concentration and distribution in soils and vegetation at Korle Lagoon area in Accra, Ghana. Cogent Environ. Sci. 2017, 3, 1405887. [CrossRef]

44. Lawal, A.O.; Audu, A.A. Analysis of Heavy Metals Found in Vegetables from Some Cultivated Irrigated Gardens in the Kano metropolis, Nigeria. J. Environ. Chem. Ecotoxicol. 2011, 3, 142-148. Available online: https://academicjournals.org/article/article1 380007572_Lawal\%20and\%20Audu.pdf (accessed on 24 September 2021).

45. Towle, K.M.; Garnick, L.C.; Monnot, A.D. A human health risk assessment of lead (Pb) ingestion among adult wine consumers. Food Contam. 2017, 4, 7. [CrossRef]

46. Kananke, T.; Wansapala, J.; Gunaratne, A. Heavy metal contamination in green leafy vegetables collected from selected market sites of Piliyandala Area, Colombo District, Sri Lanka. Am. J. Food Sci. Technol. 2014, 2, 139-144. [CrossRef]

47. Hange, K.; Awofolu, O.R. Assessment of anthropogenic influence on the level of selected heavy metals $(\mathrm{Cu}, \mathrm{Zn}, \mathrm{Cd}$ and $\mathrm{Pb})$ in soil. J. Soil Sci. Environ. Manag. 2017, 8, 113-121. [CrossRef]

48. Laumbach, R.J.; Kipen, H.M. Respiratory health effects of air pollution: Update on biomass smoke and traffic pollution. J. Allergy Clin. Immunol. 2012, 129, 3-11. [CrossRef]

49. Xie, Y.; Fan, J.; Zhu, W.; Amombo, E.; Lou, Y.; Chen, L.; Fu, J. Effect of heavy metals pollution on soil microbial diversity and Bermudagrass genetic variation. Front. Plant Sci. 2016, 7, 755. [CrossRef] [PubMed]

50. Edet, A.; Ukpong, A. The concentrations of potentially toxic elements and total hydrocarbon in soils of Niger Delta Region (Nigeria). J. Environ. Earth Sci. 2014, 4, 23-34.

51. FAO/WHO. Food additives and contaminants. In Joint FAO/WHO Food Standards Program; ALI-NORM 01/12A; Codex Alimentarius Commission: Geneva, Switzerland, 2-7 July 2001; pp. 1-289.

52. Toth, G.; Hermann, T.; Da Silva, M.R.; Montanarella, L. Heavy metals in agricultural soils of the European Union with implications for food safety. Environ. Int. 2016, 88, 299-309. [CrossRef]

53. Hu, W.; Huang, B.; Tian, K.; Holm, P.E.; Zhang, Y. Heavy metals in intensive greenhouse vegetable production systems along Yellow Sea of China: Levels, transfer and health risk. Chemosphere 2017, 167, 82-90. [CrossRef]

54. Amini, M.; Afyuni, M.; Khademi, H.; Abbaspour, K.; Schulin, R. Mapping risk of cadmium and lead contamination to human health in soils of central Iran. Sci. Total Environ. 2015, 347, 64-77. [CrossRef]

55. Kartenkamp, A. Are cadmium and other heavy metal compounds acting as endocrine disrupters? Met. Ions Life Sci. 2011, 8, 305-317.

56. Ali, I.; Damdimopoulou, P.; Stenius, U.; Adamsson, A.; Akesson, A.; Berglund, M.; Håkansson, H.; Halldin, K. Cadmium-induced effects on cellular signaling pathways in the liver of transgenic estrogen reporter mice. Toxicol. Sci. 2012, 127, 66-75. [CrossRef] [PubMed]

57. MHSPE: Ministry of Housing, Spatial Planning and the Environment, The Netherlands. Environmental Standards. Circular on target values and intervention values for soil remediation. In Dutch Target and Intervention Values (the New Dutch List), 4th ed.; MHSPE: The Netherlands, 2000; p. 8.

58. WHO (World Health Organization). Guidelines for Drinking-Water Quality; World Health Organization: Geneva, Switzerland, 1996; Available online: http:/ / www.who.int (accessed on 25 September 2021).

59. DPR-EGASPIN. Department of Petroleum Resources (DPR) and Environmental Guidelines and Standards for the Petroleum Industry in Nigeria (EGASPIN); Review of the Environmental Guidelines and Standards for the Petroleum Industry in Nigeria (EGASPIN) Department of Petroleum Resources: Lagos, Nigeria, 2002.

60. Abdu, N.; Agbenin, J.O.; Buerkert, A. Fractionation and mobility of cadmium and zincin urban vegetable gardens of Kano, northern Nigeria. Environ. Monit. Assess. 2012, 184, 2057-2066. [CrossRef] 
61. Smith, L.A. Remedial Options for Metals-Contaminated Sites; Lewis Publishers: Boca Raton, FL, USA, 1995.

62. Yusuf, K.A.; Oluwole, S.O. Heavy metal $(\mathrm{Cu}, \mathrm{Zn}, \mathrm{Pb})$ contamination of vegetables in urban city: A case study in Lagos. Res. J. Environ. Sci. 2009, 30, 292-298. [CrossRef]

63. Ezejiofor, T.I.N.; Ezejiofor, A.N.; Udebuani, A.C.; Ezeji, E.U.; Ayalogbu, E.A.; Azuwuike, C.O.; Adjero, L.A.; Ihejirika, C.E.; Ujowundu, C.O.; Nwaogu, L.A.; et al. Environmental metals pollutants load of a densely populated and heavily industrialized commercial city of Aba, Nigeria. J. Toxicol. Environ. Health Sci. 2013, 5, 1-11. [CrossRef]

64. Adagunodo, T.A.; Sunmonu, L.A.; Emetere, M.E. Heavy metals' data in soils for agricultural activities. Data Brief 2018, 18, 1847-1855. [CrossRef]

65. Masona, C.; Mapfaire, L.; Mapurazi, S.; Makanda, R. Assessment of heavy metal accumulation in wastewater irrigated soil and uptake by maize plants (Zea Mays L.) at firle farm in harare. J. Sustain. Dev. 2011, 4, 132-137. [CrossRef]

66. Schmidt, J.P. Understanding phytotoxicity thresholds for trace elementsin land-applied sewage-sludge. J. Environ. Qual. 1997, 26, 4-10. [CrossRef]

67. Khodadoust, A.P.; Reddy, K.R.; Maturi, K. Removal of nickel and phenanthrene from kaolin soil using different extractants. Environ. Eng. Sci. 2004, 21, 691-704. [CrossRef]

68. WHO, World Health Organization. Guidelines for Drinking Water Quality; World Health Organization: Geneva, Switzerland, 2008, Available online: https://apps.who.int/iris/bitstream/handle/10665/44584/9789241548151_eng.pdf (accessed on 18 August 2021).

69. Saeki, S.; Kubota, M.; Asami, T. Determination of silver in soils by atomic absorption spectrometry. Water Air Soil Pollut. 1995, 83, 253-261. [CrossRef]

70. Aigberua, A.; Tarawou, T. Speciation and mobility of selected heavy metals in sediments of the nun river system, Bayelsa State, Nigeria. Environ. Toxicol. Stud. J. 2018, 2, 1-5.

71. Moslen, M.; Ekweozor, I.K.E.; Nwoka, N.D. Assessment of heavy metals pollution in surface sediments of a tidal creek in the Niger Delta, Nigeria. Arch. Agric. Environ. Sci. 2018, 3, 81-85. [CrossRef]

72. Zhang, W.; Jiang, F.; Ou, J. Global pesticide consumption and pollution: With China as a focus. Proc. Int. Acad. Ecol. Environ. Sci. 2011, 1, 125-144.

73. Abdullateef, B.; Kolo, B.G.; Waziri, I.; Idris, M.A. Levels of heavy metals in soil as indicator of environmental pollution in Maiduguri, Borno state, Nigeria. Bull. Env. Pharmacol. Life Sci. 2014, 3, 133-136.

74. Varol, M. Assessment of heavy metal contamination in sediments of the Tigris River (Turkey) using pollution indices and multivariate statistical techniques. J. Hazard. Mater. 2011, 195, 355-364. [CrossRef]

75. Wolkersdorfer, C.; Sartz, L.; Sillanpää, M.; Häkkinen, A. Enrichment and Geo accumulation of Pb, Zn, As, Cd and Cr in soils near New Union Gold Mine, Limpopo Province of South Africa. Available online: https://www.imwa.info/docs/imwa_2017 /IMWA2017_Muzerengi_720.pdf (accessed on 18 August 2021).

76. Manoj, K.; Padhy, P.K. Distribution, enrichment and ecological risk assessment of six elements in bed sediments of a tropical river, chottanagpur plateau: A spatial and temporal appraisal. J. Environ. Prot. 2014, 5, 1419-1434. [CrossRef]

77. Ogundele, F.O.; Iwara, A.I.; Jeremiah, C.J. Heavy Metal Contents in the Soil and Leaves of Different Vegetables in Lagos State, Nigeria. Asian J. Appl. Sci. 2019, 12, 108-113. [CrossRef]

78. Kumar, N.J.I.; Soni, H.; Kumar, R.N.; Bhatt, I. Hyperaccumulation and Mobility of Heavy Metals in Vegetable Crops in India. J. Agric. Environ. 2009, 10, 29-38.

79. Eze, M.O.; Ekanem, E.O. Bioaccumulation and mobility of cadmium $(\mathrm{Cd})$, lead $(\mathrm{Pb})$ and zinc $(\mathrm{Zn})$ in green spinach grown on dumpsite soils of different $\mathrm{pH}$ levels. Bull. Environ. Pharmacol. Life Sci. 2014, 4, 85-91.

80. Khan, S.; Farooq, R.; Shahbaz, S.; Khan, M.A.; Sadique, M. Health risk assessment of heavy metals for population via consumption of vegetables. World Appl. Sci. J. 2009, 6, 1602-1606.

81. Wang, Y.; Qiao, M.; Liu, Y.; Zhu, Y. Health risk assessment of heavy metals in soils and vegetables from wastewater irrigated area, Beijing-Tianjin City cluster, China. J. Environ. Sci. 2012, 24, 690-698. [CrossRef]

82. Jadia, C.D.; Fulekar, M.H. Phytoremediation of heavy metals: Recent techniques. Afr. J. Biotechnol. 2009, 8, 921-928.

83. Jaishankar, M.; Mathew, B.B.; Shah, M.S.; Gowda, K.R.S. Biosorption of heavy metal ions using agricultural wastes. J. Environ. Pollut. Hum. Health 2014, 2, 1-6.

84. Enyoh, C.E.; Verla, A.W.; Egejuru, N.J. pH variations and chemometric assessment of borehole water in Orji, Owerri Imo State, Nigeria. J. Environ. Anal Chem. 2018, 5, 1-9.

85. Liang, Y.; Yi, X.; Dang, Z.; Wang, Q.; Luo, H.; Tang, J. Heavy metal contamination and health risk assessment in the vicinity of a tailing pond in Gangdong, China. Environ. Res. Public Health 2017, 14, 1557. [CrossRef]

86. Singh, A.; Sharma, R.K.; Agrawa, M.; Marshall, F.M. Risk assessment of heavy metal toxicity through contaminated vegetables from waste water irrigated area of Varanasi. India Trop. Ecol. 2010, 51, 375-387.

87. Isiuku, B.O.; Enyoh, C.E. Monitoring and modeling of heavy metal contents in vegetables collected from markets in Imo State, Nigeria. Environ. Anal Health Toxicol. 2020, 35, e2020003. [CrossRef]

88. Ametepey, S.T.; Cobbina, S.J.; Akpabey, F.J.; Abudu, B.D.; Zita, N.A. Health risk assessment and heavymetal contamination levels in vegetables from Tamale Metropolis, Ghana. Food Contam. 2018, 5, 1-8. [CrossRef]

89. Xue, Z.J.; Liu, S.Q.; Liu, Y.L.; Yan, Y.L. Health risk assessment of heavy metals for edible parts of vegetables grown in sewage -irrigated soils in suburbs of Baoding City, China. Environ. Monit. Assess. 2012, 184, 3503-3513. [CrossRef] 
90. Bortey-Sam, N.; Nakayama, S.M.; Ikenaka, Y.; Akoto, O.; Baidoo, E.; Yohannes, Y.B. Human health risks from metals and metalloid via consumption of food animals near gold mines in Tarkwa, Ghana: Estimation of the daily intakes and target hazard quotients (THQs). Ecotoxicol. Environ. Saf. 2015, 111, 160-167. [CrossRef] [PubMed]

91. Karimi, A.; Naghizadeh, A.; Biglari, H.; Peirovi, R.; Ghasemi, A.; Zarei, A. Assessment of human health risks and pollution index for heavy metals in farmlands irrigated by effluents of stabilization ponds. Environ. Sci. Pollut. Res. Int. 2000, 27, 10317-10327. [CrossRef]

92. Cao, S.; Duan, X.; Zhao, X.; Ma, J.; Dong, T.; Huang, N.; Sun, C.; He, B.; Wei, F. Health risks from the exposure of children to As, Se, $\mathrm{Pb}$ and other heavy metals near the largest coking plant in China. Sci. Total Environ. 2014, 472, 1001-1009. [CrossRef] [PubMed]

93. Edith-Etakah, B.T.; Shapi, M.; Penaye, J.; Mimba, M.E.; NguemheFils, S.C.; Nadasan, D.S.; Davies, T.C.; Jordaan, M.A. Background concentrations of potentially harmful elements in soils of the Kette-Batouri Region, Eastern Cameroon. Res. J. Environ. Toxicol. 2017, 11, 40-54. [CrossRef]

94. Osakwe, S.A. Contributions of abattoir activities in Delta State, Nigeria to the soil properties of their surrounding environment. J. Chem. Biol. Phys. Sci. 2016, 6, 982-991.

95. Kieri, I.B.S.; Ekpete, O.A.; Edori, O.S. Assessment of heavy metal pollution in sediments of Silver River, Southern Ijaw, Bayelsa State, Nigeria. Environ. Anal. Eco. Stud. 2021, 7, 186-193. Available online: https://www.researchgate.net/publication/34954968 3_Assessment_of_Heavy_Metal_Pollution_in_Sediments_of_Silver_River_Southern_Ijaw_Bayelsa_State_Nigeria (accessed on 26 November 2021). [CrossRef]

96. Li, B.; Wang, Y.; Jiang, Y.; Li, G.; Cui, J.; Wang, Y.; Zhang, H.; Wang, S.; Xu, S.; Wang, R. The accumulation and health risk of heavy metals in vegetables around a zinc smelter in northeastern China. Environ. Sci. Pollut. Res. 2016, 23, 25114-25126. [CrossRef] [PubMed]

97. Uddin, M.M.; Xie, B.; Peng, G.; Huang, L. Heavy metal pollution status, spatial distribution and associated ecological risks within sediments of Yundang Lagoon catchment in Xianmen, China, after 30-years continuous ecological rehabilitation. Hum. Ecol. Risk Assess. Int. J. 2020, 27, 465-482. [CrossRef] 